\title{
THE INTERNATIONAL EXPERIENCE WITH PRIVATIZATION: ITS RAPID RISE, PARTIAL FALL AND UNCERTAIN FUTURE
}

John Nellis, * Principal, International Analytics

\section{SUMMARY}

From a triumphant high in the late 20th century, esteem for privatization has significantly declined, post-2000. Politicians and businesspeople alike now take a more balanced view of its effectiveness, recognizing that privatization must happen in a supportive institutional and policy framework if it is to live up to its potential. They have also come to share a better understanding of the sociopolitical consequences - especially with regard to public opinion that privatization inevitably brings with it. This paper provides a comprehensive examination of this 21st century global shift in perception, with an emphasis on developing and emerging markets. Through a rich trove of case studies, it accounts for why privatization has slowed, analyzing current and past trends from a variety of sectors worldwide. It also offers a thorough analysis of privatization's effects on economies, societies and the political process, while giving ample space to critics' views. Although powerbrokers now tend to view privatization warily, there is good reason to believe that, due to the impact of the ongoing global economic crisis on government budgets, its day will come again. This paper, with its impressively detailed and wide-ranging grasp of the phenomenon, is essential reading for academics, policymakers and economists - the individuals who must grapple with privatization's implications when that day arrives.

\footnotetext{
* Constructive suggestions on earlier drafts were received from Anthony Boardman, Narjess Boubakri, John Earle, Alan Gelb, Nilgün Gökgür, Ira Lieberman, Michael Klein, William Mako, William Megginson, John Williamson, Charles Woodruff, Richard Van Loon and a number of the participants in the Roundtable on Public Enterprise Performance and Privatization - at which this paper was presented - at The School of Public Policy, University of Calgary, on October 5, 2011.
} 


\section{INTRODUCTION}

Worldwide, between $1979^{I}$ and the end of 1999 , more than 130 countries divested, or turned over to private management, ${ }^{2}$ at least 75,000 medium and large enterprises formerly owned and operated by the state. ${ }^{3}$ These entities were found in all economic sectors: infrastructure (e.g., telecommunications, water and sewerage, electricity generation and distribution, ports, airlines, postal services, railroads and several facets of road transport), banking, insurance, tourism, and every manner of commercial, industrial and service activity, including a zoo in Argentina and a football team in Mexico. A roughly equal number of small business units was also privatized, the bulk of them in formerly socialist states in East and Central Europe, and Central Asia.

Total proceeds to the sellers from privatization in this period are difficult to estimate, but, conservatively, exceeded \$1 trillion US [in 2000 dollars]. ${ }^{4}$ Note at once that sales proceeds are a partial and inadequate measure of privatization's scope and impact. In this period, many thousands of firms and business units, mainly in the formerly socialist countries, were divested through "voucher," giveaway and employee/management buy-out schemes yielding little or no money to the privatizing states.

By the end of the 20th century, the ranks of non-privatizing countries had dwindled to a handful (e.g., Cuba, North Korea), and, as the global economy partially rebounded from the Russian and Asian financial crises of 1997 and 1998, some states previously reluctant to privatize - e.g., Iran, Syria, India, Vietnam, Saudi Arabia and several other states in the Persian Gulf - embarked on the process. A few countries (Bahrain, Fiji, Madagascar, Gambia, Papua New Guinea) divested only one or two firms pre-2000, but others, such as Argentina, Brazil, China, Ghana, Kenya, Mexico, Pakistan, Peru and most of the formerly socialist states, privatized vast numbers of large and medium firms, more than 10,000 in the former German Democratic Republic and over 15,000 in Russia alone.

I The year in which Margaret Thatcher became Prime Minister of Great Britain. During the first Thatcher government, 1979 to 1983 , local council housing and 12 small firms were partly or fully privatized. The first major firm divested was British Telecom, in 1984.

2 The term "privatization" has been and continues to be loosely applied to a broad range of transactions, only some of which involve the complete transfer of ownership to private parties. The contracting out to private operators of a firm's non-core activities (e.g., office cleaning, vehicle maintenance), management contracts, leases and concessions - none of these necessarily involve transferring permanently a firm's productive property to private hands, but all are generally referred to as forms of privatization. The term "divestiture" is sometimes reserved for the cases where partial or full ownership of assets is legally removed from government and transferred to new private operators. Except where otherwise indicated, in this study "privatization" is used in the broader sense, encompassing leases, concessions and privatization of management, as well as partial or full ownership transfer.

375,000 is a conservative approximation. William Mako estimates that if one were to count as privatization all the various forms of private sector involvement in industries that took place in China in the 1990s, the figure might easily double or perhaps even triple. (Personal communication.)

4 Sources: The World Bank's Privatization Database for cash sales in member states of the IBRD; Sunita Kikeri and Aishetu Kolo, "Privatization Trends," World Bank, Public Policy for the Private Sector Note No. 303, Washington, DC: 2006; and the OECD's "Recent Privatization Trends in OECD Countries," OECD: Paris, 2002, for the 25 member countries that were not also borrowing countries of the World Bank (i.e., excluding the Czech Republic, Poland, Hungary, Turkey and Mexico, all OECD members, but also borrowers from the World Bank). See also Figure 1, "Worldwide Revenues from Privatization, 1988-2010," in Privatization Barometer, The PB Report, 2010, Milan, 2010, p. 6 (www.privatizationbarometer.net).

Note that (i) more than $\$ 625$ billion of the estimated total proceeds came from sales in the 25 OECD countries; (ii) the compilers of the World Bank Privatization Database readily admit that their data are not "a fully comprehensive resource. Some transactions have inevitably been missed..." due to government secrecy and sensitivity concerns; and (iii) the World Bank database does not include sales generating proceeds of less than \$1 million US. 
Support for privatization came from a steady flow of studies of the policy's impact, drawn from various regions and settings, examining firms in a variety of sectors, and assessing before and after performance using a variety of analytical techniques. While some few of these studies reported only slight differences in operations, the dominant assessment was that ownership change in and of itself contributed positively to firm performance. ${ }^{5}$ These data led the authors of a comprehensive survey of the empirical literature on privatization to state, in 1998:

The evidence is now conclusive that privately owned firms outperform SOEs [state-owned enterprises]...empirical evidence clearly shows that privatization significantly (often dramatically) improves the financial and operating performance of divested firms. ${ }^{6}$

Privatization, it appeared, had "swept the field and won the day."7

A bit more than a decade later, privatization is perceived in a less triumphant light. The policy is now not so uncritically espoused, neither by politicians, nor by representatives of the international financial institutions. Economic analysts presently take a more balanced view of its effectiveness. Few dispute the positive results of privatization of firms operating in competitive, or potentially competitive markets, but experience has yielded a deeper understanding of the complexities of implementing the policy, especially in infrastructure sectors such as electricity, railways or water and sewerage, and particularly in lower-income, less developed economies. There is a greater recognition that privatization needs to take place in a supportive institutional and policy framework if it is to live up to its potential; and there is a better realization of the socio-political challenges that inevitably accompany this always contentious activity. This is not to say that past privatizations were mistakes, or that previous analyses were in error. Rather, it is that the early, often excessive enthusiasm for, and overselling of, the policy has been replaced with a more nuanced view of its strengths and weaknesses.

5 See, for example, Ahmed Galal, Leroy Jones, Pankaj Tandon and Ingo Vogelsang, Welfare Consequences of Selling Public Enterprises. Washington, DC: World Bank, 1995; Narjess Boubakri and Jean-Claude Cosset, "The Financial and Operating Performance of Newly Privatized Firms: Evidence from Developing Countries," Journal of Finance, Vol. LIII, No. 3 (June, 1998), pp. 1081-1110; Raphael La Porta and Florencio Lopez-de-Silanes, "The Benefits of Privatization: Evidence from Mexico,” Quarterly Journal of Economics, Vol. 114, No. 4 (November, 1999), pp. 1193-1242; and O. Havrylyshyn and D. McGettigan, "Privatization in Transition Economies," Post-Soviet Affairs, Vol. 16, 2000, pp. 257-286.

6 William Megginson and Jeffrey Netter, "From state to market: A survey of empirical studies on privatization," Working Paper, New York Stock Exchange and SBF Bourse de Paris, 1998, from the abstract. (This author has added the words in brackets; the words in parenthesis are in the original.) A revised version was published as "From State to Market: A Survey of Empirical Studies on Privatization," Journal of Economic Literature, Vol. XXXIX, (June, 2001), pp. 321-389.

7 John Nellis, "Time to Rethink Privatization in Transition Economies?" in Oleh Havrylyshyn and Saleh M. Nsouli, editors, A Decade of Transition: Achievements and Challenges. Washington, DC: International Monetary Fund, 2001, p. 160. 
The purpose of this study is to examine what has happened, worldwide, but with emphasis on developing and emerging markets, regarding privatization in the post-2000 period. ${ }^{8}$ Section II summarizes available data from the last decade on what has been privatized, where, and by what methods. It accounts for why the pace of privatization has generally slowed, and compares post- 2000 trends to the previously prevailing patterns of activity, in terms of geographical and sectoral concentration of privatization, proceeds generation and mechanisms of sale. It also notes the very large number of firms still owned (at least in part) and influenced by states. Section III summarizes post-2000 arguments and information on the financial, operational and overall welfare impacts of privatization. It then examines privatization's disaggregated welfare impact; that is, on employment, service quality, access and availability and cost. It also discusses the links between privatization and corruption, and reflects on why privatization wins most economic battles but still loses the political wars. Section IV sums up.

\section{WHAT HAS HAPPENED?}

\section{The basic numbers: transactions and proceeds}

Contrasting the post- to the pre-2000 period, the first findings are that the pace of privatization slowed and the geographical centres of activity shifted. Whereas the World Bank could tally more than 8,300 cash-producing privatization transactions in 105 of its member countries in the period 1988-1999, it could count only 1,858 such transactions in 101 member countries in the period 2000-2008 (the last year for which World Bank data are available). However, privatization proceeds in these markets increased threefold, from about $\$ 150$ billion pre-2000, to $\$ 450$ billion post- $2000 .^{9}$

Privatization in OECD countries also tapered off in the period 2000-2004, in terms of numbers of sales and proceeds generated. ${ }^{10}$ According to a second database compiled by the Milanbased Privatization Barometer, privatization activity, as measured by sales proceeds, rebounded considerably in the period 2005-2008, returning close to late 1990s levels. Privatization Barometer states that privatization revenues reached record heights in both 2009 and 2010, partly through several massive share sales of SOEs in the EU states, and in China, Brazil, Malaysia and elsewhere, but mainly due to an exceptional incident: the return to the market of the massive amount of automotive and financial equity temporarily taken into state hands by the US government in $2008 .^{.1}$

\footnotetext{
8 This study builds on and updates this author's previous "Privatization: A Summary Assessment," The SAIS Review of International Affairs, Summer-Fall 2007, Vol. XXVII (No. 2), pp. 3-29. The earlier study contained discussions of why and how state-ownership became so prevalent in the first three-quarters of the 20th century, why privatization gained ground so rapidly and thoroughly, and the institutional requirements for privatization to succeed. Since there is little to add on these themes, these issues are not reviewed in this paper.

9 World Bank Privatization Database figures.

10 Bernardo Bortolotti and Valentina Milella, "Privatization in Western Europe: Stylized Facts, Outcomes and Open Issues," Chapter 2 in Gerard Roland, editor, Privatization Successes and Failures. NY: Columbia University Press, 2008, p. 36

11 Privatization Barometer, op. cit., pp. 6-7. Privatization Barometer tabulates proceeds; it does not provide breakdowns by transaction numbers, sectors or countries. This information is partially revealed in the accompanying text and explanatory articles, but, unlike the World Bank materials, the reader does not have access to the base data.
} 
The post-2000 slowdown was caused by a number of factors. First was the decline in the stock of privatizable entities. In a number of countries, a fair amount of the more easily privatized entities had been divested. A second factor was the sell-off in world equities markets after the burst of the technology bubble in September 2000. Privatization, along with other markets, fell off greatly, but then rebounded considerably between 2005 and 2007 (see Tables 1-5 below).

The enduring global crisis of 2008 to the present has had both retarding and stimulative effects on privatization - retarding in the sense that many investors and governments grew wary of undertaking expensive and risky divestiture ventures in troubled times. Moreover, the lengthy crisis has produced some re-nationalization of previously divested infrastructure, finance, mining and energy firms in several countries where leftists/populists have won elections, or where (e.g., Russia) the forms of privatization concluded were seen as particularly corrupt, encouraging the reinsertion of state control. As noted, some more temporary forms of government intervention occurred in countries hardest hit by the global turndown, including the US. Still, there has been no (at least yet) enduring re-nationalization of previously privatized commercial and manufacturing companies, despite a number of calls for such actions - save in Venezuela, where the re-nationalization fervor pre-dated the crisis.

On the other hand, the crisis stimulates privatization. Many heavily indebted, low-growth countries have few resource-generating options other than to divest their remaining SOE portfolios. In some cases, such as Greece and Portugal at the moment (and Spain, Ireland and Italy in the future?), external funders are demanding the sale of state-owned firms to improve government balances and justify financial assistance. Greece, for example, has reportedly agreed to sell off, by 2015 , some $€ 50$ billion worth of state firms. In a number of other cases, such as India, governments are voluntarily selling parts or all of their remaining SOEs to raise funds.

The slower aggregate pace masks the fact that, post-2000, privatization greatly accelerated in certain countries and sectors. Tables 1 through 4 , below, present the basic privatization data from the last decade for the developing and emerging economies of the world. Table 5 contrasts the information presented in the World Bank database to that found in Privatization Barometer. (Privatization Barometer amasses data worldwide, and has the added advantage of listing information from 2009 and 2010.)

TABLE 1: PRIVATIZATION IN DEVELOPING \& EMERGING MARKETS

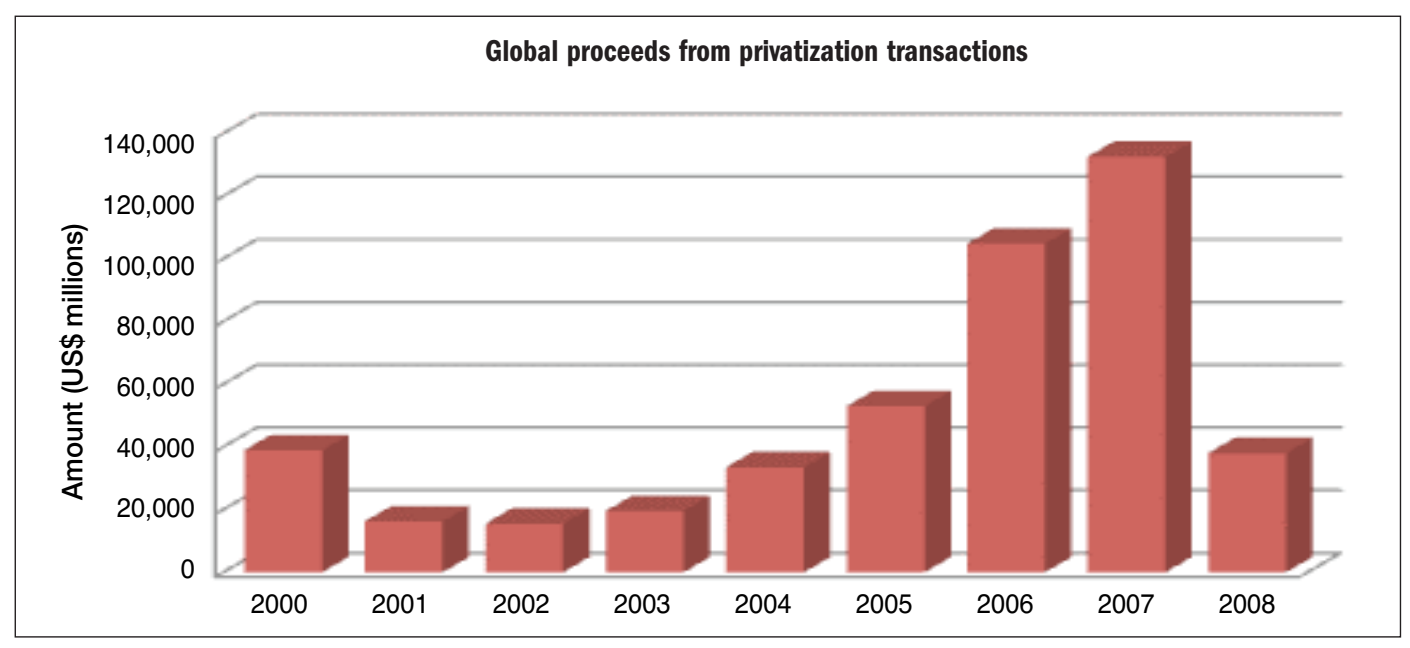


TABLE 2: PRIVATIZATION IN DEVELOPING \& EMERGING MARKETS

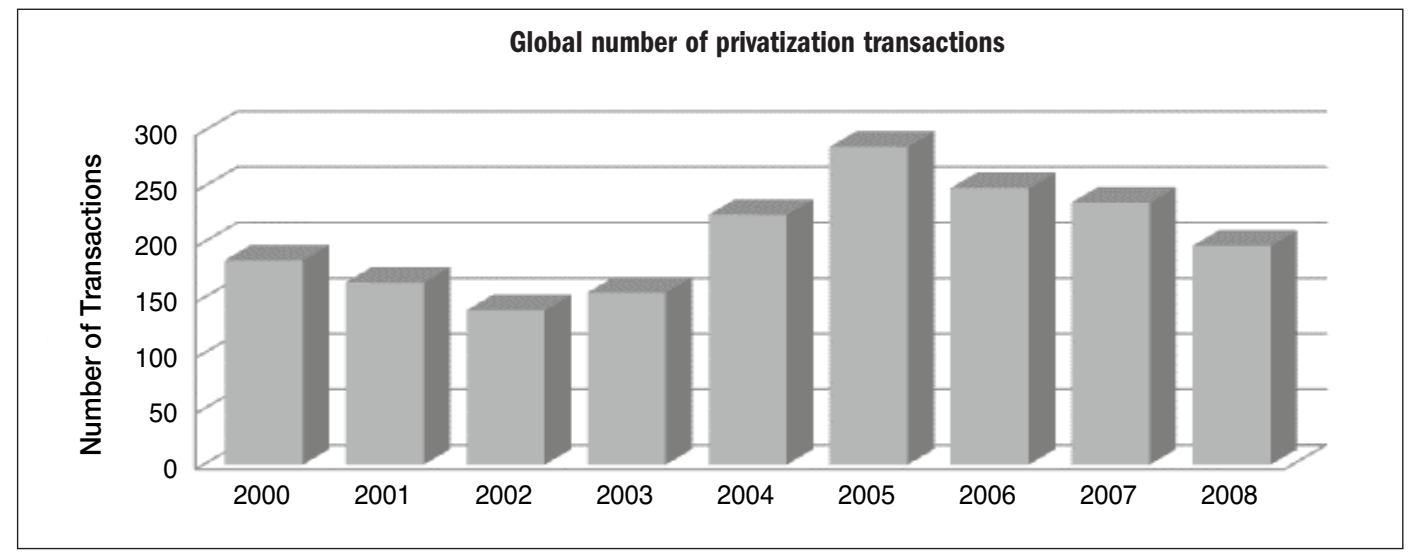

Source: World Bank Privatization Database.

TABLE 3: PRIVATIZATION IN DEVELOPING \& EMERGING MARKETS

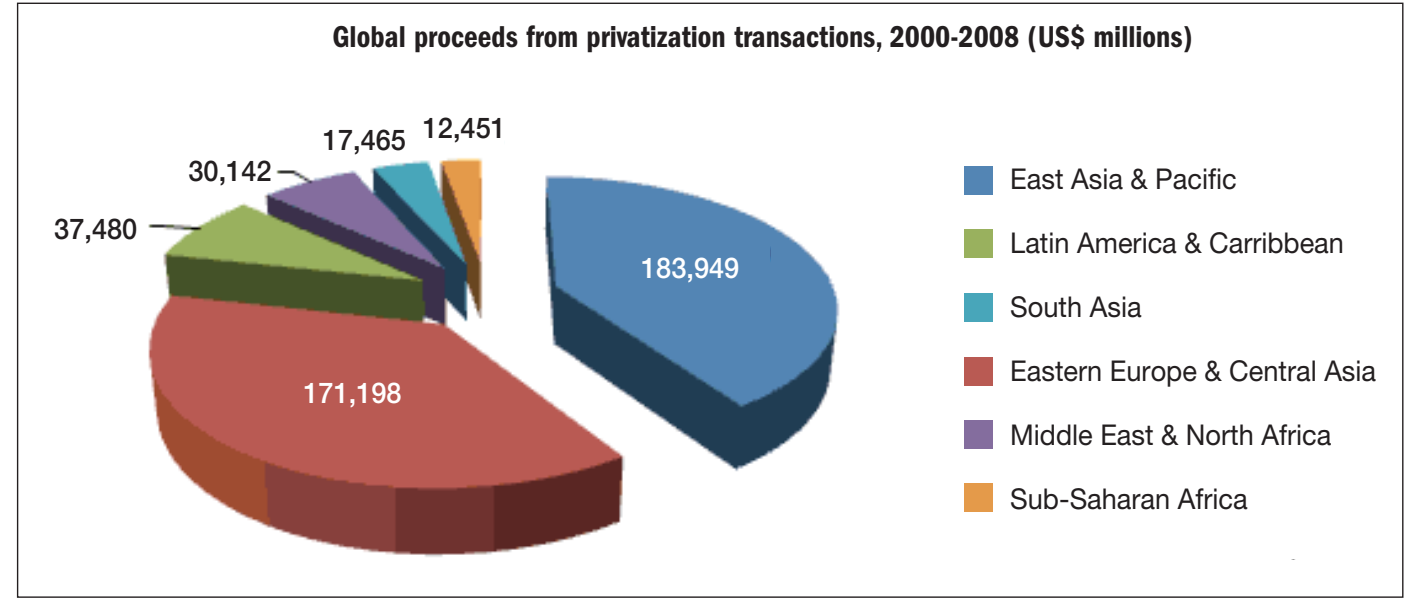

Source: World Bank Privatization Database.

TABLE 4: PRIVATIZATION TRANSACTIONS BY REgION, 2000-2008

\begin{tabular}{|c|c|c|c|c|c|}
\hline $\begin{array}{c}\text { East Europe- } \\
\text { Central Asia }\end{array}$ & $\begin{array}{c}\text { East Asia- } \\
\text { Pacific }\end{array}$ & $\begin{array}{c}\text { Sub-Saharan } \\
\text { Africa }\end{array}$ & South Asia & $\begin{array}{c}\text { Middle East } \\
\text { North Africa }\end{array}$ & Latin America \\
\hline 862 & 359 & 225 & 146 & 137 & 129 \\
\hline
\end{tabular}

Compiled by the author from the World Bank Database. Note once again that the Database does not record transactions generating less than $\$ 1$ million US. 
TABLE 5: COMPARISON OF ESTIMATED PRIVATIZATION PROCEEDS FROM THE WORLD BANK PRIVATIZATION DATABASE \& PRIVATIZATION BAROMETER DATABASE

\begin{tabular}{|c|c|c|c|c|}
\hline Year & $\begin{array}{c}\text { World Bank } \\
\text { Privat. DB Proceeds } \\
\text { US \$ billions }\end{array}$ & $\begin{array}{c}\text { Privatization Barometer } \\
\text { Total W/Wide Proceeds } \\
\text { US \$ billions }\end{array}$ & $\begin{array}{c}\text { Privatization Barometer } \\
\text { EU Proceeds } \\
\text { US \$ billions }\end{array}$ & $\begin{array}{c}\text { Privatization Barometer } \\
\text { Non-EU (includes US) } \\
\text { US \$ billions }\end{array}$ \\
\hline 2000 & 39 & 180 & 70.8 & 109.2 \\
2001 & 16.3 & 43.8 & 27.1 & 16.7 \\
2002 & 15.6 & 69.2 & 22.5 & 46.7 \\
2003 & 19.6 & 46.6 & 29.4 & 17.2 \\
2004 & 33.6 & 94 & 68.1 & 25.9 \\
2005 & 53.1 & 140 & 84.5 & 55.5 \\
2006 & 104.9 & 116 & 51.5 & 64.5 \\
2007 & 132.6 & 138 & 54.5 & 83.5 \\
2008 & 38.1 & 111 & 75.6 & 35.4 \\
2009 & & 265.2 & 55.9 & 209.3 \\
2010 & & 213.6 & 44.2 & 169.4 \\
& $\sum \$ 452.8$ bn & $\sum \$ 1.42$ trillion & $\sum \$ 584.1$ bn & $\sum \$ 833.3 \mathrm{bn}$ \\
\hline
\end{tabular}

Sources: World Bank Privatization Database and Privatization Barometer, 2010 report, Table 1. The World Bank gathers privatization information on the 144 developing countries and middle- income countries in its membership. The Privatization Database presumably includes all these plus the non-EU OECD states in its Non-EU category. It is not clear that the two institutions use the same definitions of what constitutes a privatization and how it is valued. Clearly, major discrepancies exist. In four of the nine years for which data from both sources are available, there is a fairly close fit (< $\$ 3$ billion difference) between the WB totals and the totals in PB's Non-EU category, but in the other five years the average annual difference is close to $\$ 40$ billion. Since one does not have access to PB's raw data, it is not possible to reconcile the differences. It may be that simple compositional differences in the categories account for the problem.

Prior to 2000, proceeds from sales had been highest in OECD countries, ${ }^{12}$ followed by Latin America - led by the privatization of large infrastructure and energy firms in Argentina, Bolivia, Brazil, Chile, Colombia and several others - and Asia, due to the spate of sales by China late in the 1990s. ${ }^{13}$ The number of pre-2000 transactions had been highest in the formerly socialist countries, in East and Central Europe but (to repeat) many of those privatizations had been through voucher or employee buy-out schemes, generating little or no revenue for the state.

Almost all the formerly socialist countries had retained in public ownership some very large industrial companies and many of their higher-value infrastructure firms. Post-2000, the transition states put much of these remaining portfolios on the market. In this phase they did not use vouchers - illustrating that vouchers had been more a political than an economic mechanism, designed to obtain the acquiescence of the populace in the initial shift to markets but rather cash-raising sales methods: tenders, negotiated sales, or share-issue privatizations (SIPs). As indicated in Table 3, these produced substantial revenues.

12 According to Privatization Barometer, in the period 1988-1999, 47 percent of total privatization proceeds were generated from sales in the EU states alone. Ibid.

13 Curiously, the key macroeconomic question about privatization - to what use have the proceeds been put? - has only rarely been addressed. The sole empirical study on the issue dates from 2000 . It concluded that, based on data from a sample of 18 developing and transition economies, privatization proceeds were large, that the net receipts were saved (generally used to retire debt) and not consumed, that gross transfers from governments to the firms and sectors undergoing privatization declined, that governments' fiscal positions improved, and that there was "a strong correlation... between privatization and growth." See Jeffrey Davis, Rolando Ossowski, Thomas Richardson and Steven Barnett, "Fiscal and Macroeconomic Impact of Privatization," International Monetary Fund, Occasional Paper No. 194, 2000, p. 2. 
Tables 3 and 4 also show the increasing importance of privatization in East Asia, particularly China, where, post-2000, numerous and massive initial public offerings (IPOs) were launched in finance, mining, transport, telecom, energy and manufacturing firms, reducing state equity holdings and raising investment capital for now partially (at least) private firms. In 2007, SIPs of this type, mainly in China and Russia, accounted for 90 percent of the year's revenues raised by share sales (as tabulated by the World Bank). These, in turn, accounted for two-thirds of the year's total privatization proceeds from all methods. ${ }^{14}$

In several areas a small number of high value transactions accounted for a large percentage of total proceeds. In the Middle East-North Africa (MENA) region, for example, just eight of the 137 recorded privatizations between 2000-2008 raised \$16.4 billion US, more than half the total regional sales revenues. Of 360 recorded transactions in the East Asia-Pacific region, 37 huge privatizations in China alone (in all sectors) raised $\$ 144.6$ billion US, or 78 percent of the regional total, and almost one-third of the global total for the period. Privatization Barometer notes a recent increase in mega-privatizations, pointing to the $\$ 27.5$ billion raised by the partial sale of Brazil's Petrobras to private investors in 2010, and the $\$ 22.1$ billion raised by an IPO of a portion of the equity of the Agricultural Bank of China (in the same year). The large deal phenomenon has been much less pronounced in sub-Saharan Africa: only four of 226 transactions in that region through 2008 raised more than $\$ 750$ million US.

Tables 3 and 4 indicate that privatization continued to lag in the post-2000 period in the Middle East-North Africa region, South Asia, and sub-Saharan Africa, at least in terms of proceeds generated. 86 (38 percent) of Africa's recorded 225 transactions generated proceeds of $\$ 10$ million or less, with many of these at the cut-off figure of $\$ 1$ million US. This illustrates both the depth of intrusion of past African state ownership at even the lower end of the commercial and manufacturing sector, as well as the generally poor state of the firms at time of sale. It also suggests that most African states have yet to involve private operators in their larger, highervalue infrastructure firms, though that is beginning to change.

A similar, if less pronounced, pattern of comparatively small value sales and hesitant divestiture can be seen in South Asia, which recorded only 146 transactions in the period (56 percent of these in India, a further 37 percent in Pakistan, and a few transactions each from Afghanistan, Bangladesh, Nepal and Sri Lanka).

\section{What has been privatized?}

Table 6, below, summarizes available data on which types of firms have been divested, using the five categories employed by the World Bank Database: energy (oil and gas mainly), financial (banks, insurance, leasing firms), infrastructure (utilities plus all forms of transport including toll roads, ports, railways, container terminals, etc.), manufacturing and services (anything operating in competitive sectors) and primary (mining and extractive industries).

\footnotetext{
14 Sunita Kikeri and Verena Phipps, "Privatization Trends: A Record Year for Initial Public Offerings in 2007," Viewpoint: Public Policy for the Private Sector, World Bank, 2007, p. 1.
} 
TABLE 6: SECTORAL COMPOSITION OF PRIVATIZATIONS, 2000-2008

\begin{tabular}{|l|c|c|c|c|c|c|}
\hline \multicolumn{1}{|c|}{ Sector } & \# Countries & \# Transactions & $\begin{array}{c}\text { Proceeds } \\
\text { (in US } \\
\text { \$ billions) }\end{array}$ & $\begin{array}{c}\text { \# Large } \\
\text { Transactions } \\
\text { (> \$ 1 bn) }\end{array}$ & $\begin{array}{c}\text { Amount } \\
\text { raised } \\
\text { in large T's }\end{array}$ & $\begin{array}{c}\text { \% Sector } \\
\text { Proceeds } \\
\text { from large T's }\end{array}$ \\
\hline Energy & 26 & 84 & $\$ 69$ & 14 & $\$ 54$ & 78 \\
Financial & 45 & 303 & $\$ 149$ & 23 & $\$ 127$ & 85 \\
Infrastructure & 91 & 671 & $\$ 157$ & 33 & $\$ 77$ & 49 \\
Manuf. \& Services & 58 & 675 & $\$ 61$ & 15 & $\$ 34$ & 56 \\
Primary & 30 & 97 & $\$ 17$ & 5 & $\$ 11$ & 66 \\
Totals & 1830 & $\$ 453$ & 90 & $\$ 303$ & \\
\hline
\end{tabular}

Source: Compiled by the author from the World Bank Privatization Database. 28 privatizations considered unclassifiable in the database are not included.

Worldwide, infrastructure privatizations have been just about as numerous as those in the leading category, manufacturing and services. Infrastructure transactions generated the most proceeds, and the largest number of high-value deals. But note that less than half the number of financial sector transactions generated almost as much total proceeds as infrastructure.

Moreover, the average size of large transactions in finance ( $\$ 5.5$ billion) was more than twice that of the large sales in infrastructure ( $\$ 2.3$ billion). Clearly, at least prior to the 2008 crisis, the financial sector was eliciting great investor interest.

Table 6 reinforces the conclusion that a relatively few divestitures account for the bulk of the proceeds; five percent of privatizations by number accounted for 67 percent of revenues.

The sectors generating the most investor interest, in terms of highest prices paid, have been banking and insurance, followed by telecommunications, and then energy and mining. Globally, telecommunications has generated great private interest and consistently produced high-value deals. For example, four of the eight largest privatizations in the MENA region post-2000 were in telecommunications (Egypt, Morocco, Tunisia and Iraq). Telecom also produced three of the four largest transactions in Africa and the largest South Asian privatization (the $\$ 2.5$ billion sale of Pakistan telecommunications). Telecom sales in Croatia, Serbia, the Czech Republic and Turkey were among the largest transactions in the EuropeCentral Asia region. Latin American examples are absent simply because most of the telecom firms in the region had already been sold pre-2000. In addition, telecom sales produced the highest revenues in Western European divestitures, followed by privatization of utilities and financial firms. ${ }^{15}$

\section{What has not been privatized?}

Despite massive activity pre-2000, and the smaller but still significant number of divestitures post-2000, a surprisingly large number of firms and a huge amount of valuable assets remain in state hands in the developing economy/emerging market world, and, unexpectedly, in OECD countries as well. This is particularly true in the infrastructure sector (outside of telecommunications, and even there, more than half of developing countries continue to own

15 Bortolotti and Milella, op.cit., Figure 2.7, p. 39. 
and operate the fixed-line portion of the sector). Numerous privatizations, of management if not of ownership, have indeed taken place in electricity generation and distribution, in water and sewerage and various parts of transport. However, most states in Africa, the Middle East and Central and South Asia still retain ownership and operation of the bulk of their utilities. This is also the case in banking and insurance. ${ }^{16}$ Moreover, even in the regions where privatization has succeeded in significantly reducing the levels of GDP accounted for by stateowned firms - i.e., Latin America and Europe and Central Asia - one finds some outlying countries where the process has not advanced very far, if at all (e.g., Venezuela, Honduras, Paraguay, Guyana, Suriname, Belarus, Turkmenistan, Tajikistan). ${ }^{17}$

These and many other developing countries persist in defining firms or sectors as strategic, supposedly necessitating a state ownership presence, even though they operate in competitive, or potentially competitive markets. State-owned Air India, for example, has seen private competitors take 85 percent of the internal Indian air travel market; its annual losses now exceed $\$ 1$ billion US, and domestic and foreign critics question the quality and safety of its operations. ${ }^{18}$ Nonetheless, the Indian Minister of Civil Aviation is quoted as saying "There is no question of Air India being shut or privatized." Many countries continue to make similar decisions about loss-making state-owned airlines, and other visible, large employers.

In addition, many privatizations concluded in China, India and Western Europe, have been sales of partial ownership stakes on stock exchanges. Privatization Barometer notes that “...European governments hold at least two-thirds of a trillion dollars worth of stakes in partially privatized firms...." ${ }^{19}$ Major and often controlling stakes continue to be held by state agents, actively supervised by direct government board appointees or by state-owned asset management companies or development banks responsive to state directives. Is this really privatization?

On the one hand, minority private shareholding has, in a number of cases, raised firm profitability, productivity and investment. ${ }^{20}$ On the other, the state is rarely a shareholder like any other. From the viewpoint of the firm, a continuing state presence has benefits and costs: states possess the incentives and powers both to skew market outcomes in favour of their holdings, and to deflect firm managers from profit-maximizing behaviour in order to achieve non-commercial objectives. On historical average, in the developing world at least, the costs of the latter have outweighed the benefits of the former.

16 See Sunita Kikeri and Aishetu Kolo, "State Enterprises: What Remains?" Public Policy for the Private Sector, Note Number 304, World Bank, 2006.

17 The last are the only three of the 29 transition countries still ranked at the lower two numbers on the EBRD's fourpoint "large-scale privatization" scale. In addition, Belarus and Turkmenistan are the only two countries scoring low on the "small-scale privatization" scale. See European Bank of Reconstruction and Development, Transition Report 2010: Recovery and Reform. London: EBRD, Table 1.1, p. 4.

18 "Criticism of State-Owned Air India Grows," New York Times, May 26, 2011, Kindle Edition, 2nd story in the Business Section.

19 Privatization Barometer, op. cit., p. 5 .

20 Nandini Gupta, "Partial Privatization and Firm Performance," Journal of Finance, Vol. 60, Issue 2 (April, 2005), pp. 987-1015, found this in India, as did M. G. Pollitt in Norway's oil industry ("The Welfare Implications of Oil Privatization: A Cost-Benefit Analysis of Norway's Statoil," University of Cambridge, Faculty of Economics Working Paper No. 0912, March, 2009); as did Loc, Lanjouw and Lensinck in firms partially privatized in Vietnam's "equitization" program (Truong Dong Loc, Ger Lanjouw and Robert Lensinck, "The impact of privatization on firm performance in a transition economy: The case of Vietnam," Economics of Transition, Vol. 14, No. 2, 2006, 349-389. As noted below, partial privatization has been found to be much less effective in bank, rail and telecommunications divestitures. 
The overall point is that while the massive amount of post-2000 divestiture through IPOs has greatly increased the percentage of assets classed as privately owned, it has probably not produced an equivalent decline in the involvement of states in productive affairs.

In sum, post-2000, the number of recorded privatizations in the 144 client countries of the World Bank diminished to less than a quarter of those logged in the pre-2000 period. But the proceeds generated trebled, as countries shifted from giveaway schemes to cash sales, and as more countries started to put the higher-value finance, infrastructure, energy and mining firms on the sales block.

China, in particular, assumed a leading position in privatization. Pre-2000, the World Bank could count 140 privatizations in China, compared to 183 transactions post-2000. But almost all of these earlier sales had involved comparatively low-value manufacturing and service firms. The only mega-sale in the earlier period was the two-tranched privatization of Hong Kong Telecom, generating a total of $\$ 6.1$ billion. Only three of the other pre-2000 sales fetched over $\$ 500$ million, and most averaged less than $\$ 100$ million. Post-2000, the average sale price of Chinese divestitures increased greatly. Nonetheless, as of 2009, SOEs in China continued to account for roughly one-third of industrial production, about 30 percent of GDP, and employed 30 percent of the total labour force..$^{21}$ Clearly, even if the number of firms actually divested, in whole or in part, is much larger than the figure tabulated by the World Bank, there is considerable scope for further action.

Regrettably, the World Bank Privatization Database does not include any post-2008 data. The most recent statement from the database managers stated, not surprisingly, that in 2008, privatization activity "declined sharply" compared to 2006 and 2007. However, they noted that "preliminary data suggest a pickup in activity in 2009," led by large sales in manufacturing in China, large IPOs in energy and infrastructure in India, Poland and Turkey, and telecom privatizations in Mali and Burkina Faso. They confirm that the current crisis generates pressure for states to raise revenue from privatization, citing the government of India's decision to require all remaining state-owned firms to sell at least 10 percent of their shares on local exchanges. ${ }^{22}$ Many other cash-strapped governments must be thinking along similar, if not more dramatic lines.

Data provided by the Privatization Barometer indicate a considerable slowdown in the pace of sales in OECD/EU countries in the period 2000-2004, followed by a marked increase in proceeds in the years 2005-2008, with even greater increases, to record-setting levels, in 2009 and 2010 (Table 5).

\footnotetext{
21 Junyeop Lee, "State-Owned Enterprises in China: Reviewing the Evidence," OECD Occasional Paper, OECD Working Group on Privatization and Corporate Governance of State-Owned Assets, 2009, pp. 6-7.

22 Sunita Kikeri and Matthew Perault, "Privatization Trends: A Sharp Decline but no Widespread Reversals," Viewpoint, Public Policy for the Private Sector, Note Number 332, World Bank, May 2010, p. 4.
} 


\section{ASSESSMENTS OF IMPACT}

After 2000, some of the bloom came off the privatization rose. Concerns of various types emerged, or were more frequently and intensely expressed.

\section{Problems with Theory and Method}

One thread of criticism questioned the methods employed by studies reaching pro-privatization conclusions. Some accepted that firm performance tended to improve post-privatization, but asked the question, why? Ownership change had rarely been introduced as a stand-alone reform. Normally it was but one element in a package of policies aimed at increasing openness and competition. Perhaps it was not privatization per se that accounted for the perceived positive operational changes, but rather exposure of the firm to competition or some other policy element introduced by general liberalization? Even if ownership change was among the factors at work in improving performance, what percentage of the variance could be explained by which variable? ${ }^{23}$ The methods employed in most earlier studies did not, or did not sufficiently, sort out these factors. Perhaps ownership change was receiving undue credit?

A second set of critics noted that a number of the early studies showing highly positive changes post-privatization had mainly looked at firms divested by share-issue methods or IPOs. This ran the risk of selection bias. That is, firms sold through share issues "...tend to be the largest and usually the most profitable SOEs, which due to intense restructuring preprivatization are certainly the easiest to privatize." 24 Perhaps it was not that privatization made firms better; rather, it was that the better or higher-potential firms were those chosen to be privatized. The selection bias argument was also made against studies of country privatization programs where share-issuing had not been used. Authorities, eager to show success, may have led off with the higher-potential assets. ${ }^{25}$ Thus, analysts cautioned against accepting the blanket endorsements of privatization offered in earlier studies, on the grounds that they might be based on the experience of atypical sets of firms.

A third methodological criticism was that the period of post-privatization operations looked at was too short, and that early studies had mostly focused on firm performance shortly before and after the privatization event. Perhaps improvements attributed to privatization were more due to general shifts in the medium-term business cycle affecting all firms, public or private and this would have been more apparent had a longer timeframe been studied, and had more attention been paid to with-and-without comparisons. Some also argued that a longer timeframe would allow one to perceive and calculate "regressive distribution effects" arising from the changes. ${ }^{26}$ Taking these into account might alter the assessment of privatization.

23 This argument had surfaced prior to 2000. See Pankaj Tandon, "Welfare Effects of Privatization: Some Evidence from Mexico," Boston University International Law Journal, Vol. 13, No. 2 (1995), pp. 329-49. See also the general discussion in Gerard Roland, "Public and Private Ownership in Economic Theory," in Roland, ed., op. cit., Chapter 1, pp. 9-31.

24 Bortolotti and Milella, op. cit., p. 58.

25 For example, a study in the Czech Republic found "....strong evidence that more profitable firms were privatized first." Nandini Gupta, John C. Ham and Jan Svejnar, "Priorities and Sequencing in Privatization - Theory and Evidence from the Czech Republic," William Davidson Institute Working Paper No. 323, University of Michigan, September, 2001, from the abstract. Several other studies confirm the use of this tactic in a number of sectors - but not in banking, where governments tend first to put the major loss-makers on the sales block (as noted in the article by Boubakri et al., 2005, summarized in capsule no. 4, in the Annex, below).

${ }^{26}$ See, for one careful example of many arguments along these lines, Massimo Florio, The Great Divestiture: Evaluating the Welfare Impact of the British Privatizations. Cambridge: MIT Press, 2004. 


\section{Problems of Implementation}

A rather different line of criticism centred on the manner in which privatization was implemented. There were several strands to this argument:

- Much more could have and should have been achieved in terms of efficiency enhancement, consumer protection and distributive outcomes had market liberalization and regulatory reforms been pursued as aggressively as ownership change (this criticism was made, in particular, regarding privatization of infrastructure firms in electricity, water and telecommunications);

- Privatization in the absence of core institutional underpinnings predictably produced negative distributional and social consequences (in the transition economies in general with Russia as the prime example); ${ }^{27}$

- The application of sector reforms and privatization strategies used in infrastructure in developed economies could not and did not produce the same outcomes in low-income, institutionally weak states, especially regarding infrastructure. ${ }^{28}$ Approaches to electricity reform, say, that worked in the UK proved much harder to launch and succeeded less, and less often, in Tanzania.

27 The dubious legality and patent unfairness of privatization outcomes in many transition countries led respected observers, including Nobel-winning economists Kenneth Arrow and Joseph Stiglitz, to castigate privatization as thus practiced, and criticize those who had assumed that ownership change could and would, more or less by itself, overcome institutional deficiencies regarding the rule of law, property rights, enforceability of contracts, impartial public sector, etc. As Stiglitz put it, privatizing in the absence of a market-supporting "institutional infrastructure" was a serious mistake that could and did "lead more to asset-stripping than wealth creation." See his "Quis Custodiet Ipsos Custodes? Corporate Governance Failures in the Transition," Annual European World Bank Conference on Development Economics, Paris: June, 1999, p. 7. For a detailed argument on how privatization should have been conducted, see Bernard Black, R. Kraakman and A. Tarassova, "Russian Privatization and Corporate Governance: What Went Wrong?," Stanford Law Review, Vol. 52 (2000). For hair-raising tales of how Russian privatization was practiced, see Ira Lieberman and Rogi Veimetra, "The Rush for State Shares in the "Klondyke" of Wild-East Capitalism: Loans-for-Shares Transactions in Russia," The George Washington Journal of International Law and Economics, Vol. 29 (N0. 3), 1996, and Chyrstia Freedland, Sale of the Century: Russia's Wild Ride from Communism to Capitalism. London: Crown Business Books, 2000. Finally, for counter-criticisms arguing that privatization in transition states, for all its faults, was essential, ultimately beneficial, and could not have been carried out in a fundamentally different manner, see Andrei Shleifer and Daniel Treisman, Without a Map: Political Tactics and Economic Reform in Russia. Cambridge: MIT Press, 2000; Anders Aslund, How Capitalism was Built: The Transformation of Central and Eastern Europe, Russia and Central Asia. Cambridge: MIT Press, 2007, Chapter 6, "Privatization: The Establishment of Private Property Rights;" and John Nellis, "Leaps of Faith: Launching the Privatization Process in Transition," Chapter 2 in Ira Lieberman and Daniel Kopf, eds., Privatization in Transition Economies: The Ongoing Story, New York, Elsevier, 2008, pp. 81-136.

28

Behind this simple sentence lies a complex wealth of theoretical reasoning and empirical analysis. Most infrastructure privatizations, worldwide, have been based not on divestitures, but on concession or lease contracts negotiated between the state and a private operator. In these, the state retains the title to the assets, but management is turned over to private hands, often for lengthy periods of time. But drawing up "time-consistent, enforceable contracts that cover all the contingencies that might arise" between the owner and managers of the assets (Guasch, 2004, p. 142) has proven exceedingly difficult, particularly in less developed countries. The prevalence of "incomplete contracts" has led to faulty concession design, which, in turn, has led to demands from one or the other of the partners that the terms of the agreement be renegotiated well before the expiry of the contract period. Sometimes renegotiation has been initiated by the private operator, who demands better terms or increased compensation; sometime the government has insisted on renegotiation on the grounds that service quality or quantity goals, or other aspects of the contract, are not being met. Guasch lists 237 such infrastructure contract renegotiations in just seven Latin American countries in the period 1990-2000. There is little reason to suspect the numbers have declined in the last decade. Renegotiations have proven very costly to privatizing governments in both financial and political terms, and, for a time, severely weakened their interest in using concessions and leases with the private sector. Equally, the frequency of renegotiations and the onerous and drawn-out nature of the process, depressed, again for a time, investor interest. For example, the value of private participation in infrastructure contracts in developed countries declined dramatically from $\$ 145$ billion US in 1997 to around \$50 billion US in the period 2001-2003 (Source: World Bank Infrastructure Projects Database, Global Data 2008). Guasch argues that the capacity to draw up more complete contracts is associated with income levels. See J. Luis Guasch, Granting and Renegotiating Infrastructure Concessions. Washington: World Bank, 2004. See also Clive Harris, "Private Participation in Infrastructure in Developing Countries," World Bank Working Paper No. 5, 2003. 
All these criticisms were variations on the theme that things other than ownership matter, and that it was sub-optimal and often counterproductive for policy-makers to focus so heavily on ownership change per se.

\section{Problems of Consequences}

The most serious criticism under this sub-heading is simple to state: some assessments emerged that either did not find the expected efficiency improvements in a studied set of privatized firms, or found that the differences were less than anticipated or "hard to detect." 29 For example, Florio's ${ }^{30}$ cost-benefit study of privatization in the UK concluded that the efficiency effects of divestiture were positive, but far less than had been trumpeted by the government. A study of 25 privatized Italian firms uncovered only modest, statistically insignificant post-privatization gains in profitability, real sales per employee, output or leverage - though it did find that the privatized firms generated much more investment. ${ }^{31}$ A survey of firm-level studies in a set of transition countries found no significant effect of privatization on several aspects of performance. ${ }^{32}$

These mounting criticisms and concerns, as well as some highly publicized failures of privatizations in water and electricity, and the realization that politicians and proponents in a number of countries had seriously oversold the ease of introducing the policy, the size of privatization's benefits and the rapidity with which they would occur, combined with the downturns in markets to lead to a reconsideration of the policy. ${ }^{33}$

And yet, as is shown below, the vast majority (but not all) of firm studies or surveys in most countries and sectors continued to find positive post-privatization performance changes in terms of lowered costs, improved labour efficiency, increased outputs, higher returns to owners and shareholders, and, very often, increased investment post-transaction. At the microeconomic level of the firm and its owners, privatization has been shown rarely to do any harm and most often to result in performance improvements and efficiency gains, frequently significant in size. In many instances the sellers also benefited, due not simply to the sales proceeds, but also to the reduced flow of government subsidies to loss-making firms, and the inflow of corporate

30 Op. cit.

31 Andrea Goldstein and Guisieppe Nicoletti, "Privatization in Italy 1993-2002: Goals, Institutions, Outcomes and Outstanding Issues," Paris, OECD Development Center Working Paper, 2003.

32 Alan Bevan, Saul Estrin and Mark Schaffer, "Determinants of Enterprise Performance During Transition," Birmingham, UK: Centre for Environmental Research and Training, University of Birmingham, Working Paper No. 3,1999 .

33 The criticism of privatization by analysts (the far more widespread popular criticism of the process is discussed below in Section IV) contributed to, and was at the same time influenced by the rethinking that occurred concerning the Washington Consensus. This was a list of 10 liberal policy measures, compiled in 1990, thought to summarize official Washington's view of what developing countries needed to do to reform and grow. Privatization was one of the ten reforms. (John Williamson, "What Washington Means by Policy Reform," Chapter 2 in John Williamson, ed., Latin American Adjustment, Washington, D.C., Institute of International Economics, 1990.) By 2000, this set of policy prescriptions was receiving substantial, sustained criticism from a number of sources: developing country government officials, aid activists and NGOs, and a number of economists, including big names such as Dani Rodrik and Joseph Stiglitz. The claim was that the policy set did not produce growth, or enough of it; that the growth it did produce was ill-distributed; and that countries such as Malaysia, China and others had achieved more and better growth without adopting all these policies, and sometimes, indeed, by adopting actions the exact opposite of those recommended. 
taxes from now-profitable companies. This has particularly been the case in manufacturing and service firms privatized into competitive markets (or markets easily rendered competitive, for example, by opening them to imports). Both developing and of course socialist countries possessed many such firms in their SOE portfolios. ${ }^{34}$

Note that in most countries, the very large amount of privatization that has taken place in the manufacturing/service areas - breweries, hotels, cement, tobacco, machine tools, food production, etc. - tended and tends to be assessed positively by consumers, voters, and economists alike. ${ }^{35}$ This is also true of the large amount of small-scale - e.g., shops, storefront retail outlets, trucking firms, kiosks, micro-enterprises - privatization that took place in the transition economies; this has been an unquestioned success.

In both OECD and non-OECD countries, most of the problems that have occurred, and the most frequently expressed and intense criticisms expressed, have centred on infrastructure privatizations, followed, to a far lesser extent, by transactions in finance and energy. Further, the bulk of criticisms of infrastructure privatization have been focused on the water and electricity sectors. Here, the key complaint is that while firm operational and financial performance may have improved, a disproportionate share of the benefits have flowed to the new owners. The claim is that privatization's impact on general economic welfare has been marginal or negative.

\section{The Welfare Issue}

This could well be the case. Improved firm performance in terms of profits and returns to shareholders is an incomplete measure of privatization's utility. The privatized firm could be doing better while the general economy is doing worse. Post-sale improvements might be due to government giving the company a monopoly position, or awarding it some other cost-reducing concession in terms of policy, tax breaks, exemptions from customs duties or social security payments, or special deals on input pricing, etc. Thus, improved firm performance might be a consequence of costs imposed elsewhere in the broader economy, and these costs might be sufficient to produce a decrease in overall welfare in the system. (Selling governments may award these concessions to raise the sales price, reward political allies or protect an industry regarded as strategic, in payment for a bribe, or simply by following bad advice.)

Ideally therefore, assessments should examine the welfare impact of privatizations using some form of cost-benefit analysis. These would measure both the overall economic effects of the transaction(s), and calculate how any gains or losses due to ownership change - and only to ownership change - are distributed among all relevant actors in the process; typically, the selling government, the new owners, workers, consumers and competitors. In addition, one would need to estimate the counterfactual; that is, what would have happened had the firm remained in public hands (e.g., perhaps improved performance stems from a change in technology; perhaps the innovation would have been adopted by the public firm).

34 As noted in Table 4, transactions in manufacturing account for the largest number of privatizations.

35 Consumers have usually been pleased by the increased quantity and/or quality and reliability of a good or service produced, but have often expressed dissatisfaction when the new owners of the firms are foreign (e.g., South Africans in Tanzania and Zambia; Russians in Estonia, "Asians" in Kenya, etc.). Consumers also express fears of price increases. Often, these either do not occur, are modest, or are offset by quality/quality improvements (see Section IV). 
A fair number of studies using this approach have been conducted.$^{36}$ Because of their comprehensive nature they are regarded as the gold standard in privatization assessments. But they are relatively few in number. The problem is that the method is extremely demanding in terms of information concerning the before and after performance of the firm, the isolation of the effects of ownership change from the effects of accompanying policy changes, and the precise calculation of the losses and gains, due to privatization, and their differing allocation to relevant groups of actors. In particular, the construction of the counterfactual inevitably involves some "crystal ball gazing." ${ }^{37}$ The extraordinary data demands and methodological and interpretational complexities explain the comparative dearth of studies using this approach.

Nonetheless, all of the cost-benefit/welfare impact studies that this author has uncovered, preor post-2000, as well as an overwhelmingly high percentage of the larger set of privatization studies using non-counterfactual methods, ${ }^{38}$ conclude that privatization of infrastructure does contribute positively to overall economic welfare, often significantly so. ${ }^{39}$

In sum, the evidence shows that privatization tends generally, but not inevitably, to result in increases in efficiency in the use of inputs, increased output, increased profits and returns to shareholders; and that these results, while most common in manufacturing firms, are found across sectors, including in infrastructure (though with less intensity and more caveats). A good percentage of studies also conclude that privatization contributes to aggregate welfare, meaning that the process does contribute to gains in total available economic resources in a society.

Large questions remain: (i) have the privatization methods used come close to maximizing potential welfare gains; (ii) how have the aggregate gains been distributed; and (iii) why, if the overall results are generally good, do so many in the general public continue to distrust and oppose privatization?

${ }^{36}$ See, for example, Galal et al., op. cit.; Florio, op. cit.; David Newbery and M. G. Pollitt, The Restructuring and Privatization of Britain's CEGB: Was it Worth It?.” Journal of Industrial Economics, Vol. 45, No. 3, 1997, pp. 269303; P. Domah and M. G. Pollitt, "The Restructuring and Privatization of Electricity Distribution and Supply Businesses in England and Wales: A Social Cost-Benefit Analysis," Working Paper No. 7, University of Cambridge Department of Applied Economics, 2000; Rafaella Lisboa Mota, "The Restructuring and Privatization of the Electricity Distribution and Supply Businesses in Brazil: A Social Cost-Benefit Analysis," Working Paper 16, University of Cambridge, Department of Applied Economics, 2003; and Leroy Jones, Yahya Jammal, Nilgün Gökgür and Sunita Kikeri, "Doing Privatization Right: What it Takes to Maximize Gains in Low-Income Countries," World Bank, Viewpoint No. 319, March, 2008. The prolific Pollitt, with a number of colleagues, has produced Cambridge Working Papers calculating the costs and benefits of electricity privatization in Ireland, Scotland, Argentina and Chile; and he has done the same for railway privatization in Great Britain, and the partial privatization of Norway's oil industry (Pollitt, 2009, op. cit.). See also Sang-Ho Lee, "Welfare Improving Privatization Policy in the Telecommunications Industry," Contemporary Economic Policy, Vol. 24, Issue 2, April, 2006, pp. 237-248, and Anthony E. Boardman, Claude Laurin, Mark A. Moore and Aidan R. Vining, "A Cost-Benefit Analysis of the Privatization of Canadian National Railway," Canadian Public Policy, Vol. 35, No. 1, March, 2009, pp. 59-83.

37 The phrase is David Newbery's. Others who have used this approach agree: "In a study of this sort, innumerable choices of parameter values and other assumptions are made on the basis of judgments or educated guesses. This obviously leaves a lot of room for subjectivity." Galal et al., op. cit., p. 536.

38 See, for a start, the 12 studies listed in footnote 38 of John Nellis, "Privatization: A Summary Assessment," op. cit., p. 26.

39 The Annex presents capsule summaries of a fairly representative sample of the post-2000 scholarly findings on the impact of privatization. 


\section{Winners and Losers}

Privatization increases efficiency, rewards the new owners, generally improves the fiscal position of the selling government and increases societal net resources. What, then, is the problem?

The complaint is that regardless of the association between privatization and net societal gains, the distribution of these gains has been unequal and thus unfair. In rough order of frequency and intensity, the leading public perceptions and complaints are that privatization, regardless of its efficiency effects:

- Increases unemployment;

- Leads to higher prices, especially of essential services such as water and electricity, and reduces access to these services, particularly for the poor;

- Rewards the rich, the agile, the foreign and the corrupt at the expense of the average, local, honest citizen.

\section{A. EMPLOYMENT}

Many of the impact assessments previously cited, as well as a number of those summarized in the Annex to this paper, did find substantial labour-shedding, both by selling governments in the run-up to privatization, and by the new owners or managers post-transaction (and the comparative lack of labour shedding was, in the case of British Rail, seen as a flaw; see summary no. 7 in the Annex). Layoffs of 25 percent of the pre-transaction work force have not been uncommon, and in some cases the percentage has been much higher. Chong and Lopezde-Silanes surveyed 308 privatized firms in 84 developing and transition countries and found that 78 percent of their sample reduced employment after sale. ${ }^{40}$ It appears that privatization, at least initially, most often reduces employment levels in the affected firms.

The response to this complex issue is multifaceted. First and obviously, loss of jobs is always a painful blow for the affected workers. But the fact is that overstaffing and low labour productivity levels have long plagued SOEs, and that in most cases governments have proven unwilling or unable to deal with the issues either by rationalizing employment or by subsidizing the firms sufficiently to allow them to fulfill their functions and cover their costs while maintaining excess labour. Removal of excess labour is a sine qua non if firms, particularly infrastructure firms, are to be placed on a sustainable and subsidy-free financial footing. There is no economic and not much of a moral argument for the taxpayer to support indefinitely unnecessary and unproductive employees.

Second, while the numbers of workers dismissed through privatization can mount to an impressive absolute size, especially in notoriously overstaffed SOEs such as railways in Brazil and Argentina, the total number of people laid off is usually a small fraction of the country's

40 Alberto Chong and Florencio Lopez-de-Silanes, "Privatization and Labour Force Restructuring around the World," World Bank, Policy Research Working Paper No. 2884, September 2002, p. 7. 
total labour force. ${ }^{4 l}$ Privatization's contribution to overall unemployment levels has generally been modest, except in a few exceptional cases, such as that of Nicaragua. Third, many of the welfare analyses of privatization that have specifically attempted to measure the impact on workers have concluded that labour was not much harmed, because the severance packages paid out by government were sufficient to tide them over until they obtained new employment ${ }^{42}$ (though this sort of calculation does not take into account issues such as changes in wage levels, fringe benefits and security of tenure). Fourth, to mute or forestall criticism of privatization-induced layoffs, a number of privatizing countries have stipulated in their privatization legislation that no dismissals can occur; or that any worker dismissed from the firm due to privatization would be offered an equivalent public service or SOE position (e.g., Kuwait, Malaysia and Sri Lanka). Fifth, almost all privatizing countries have constructed generous severance packages to entice workers to leave voluntarily, and/or to soften the blow for those departing involuntarily. Most governments far prefer the former to the latter; offering inducements for early retirement is widely viewed as the optimal approach. Severance arrangements in South Asia have been especially liberal, with average payouts per worker amounting to two or three years of salary (e.g., India and Bangladesh). ${ }^{43}$ In most other countries, the established severance rules have been modified and benefits expanded for those laid off due to divestiture. Governments have also deployed many other labour-related incentives or cushions including retraining and relocation programs, and free or reduced-price distribution to workers of shares in the newly privatized firms.

Sixth, and finally, some important recent research based on long-term studies, with annual observations, of the relationship between privatization, wages and employment, questions earlier assessments that privatization usually results in increased unemployment. Brown, Earle and Telegdy looked at universal panel data on 30,000 privatized firms in Hungary, Romania, Russia and Ukraine from the pre-transition period through 2005-06. Contrary to conventional wisdom, they found "no evidence of large negative impacts of privatization on either employment or wages." ${ }^{\prime 4}$ Moreover, the authors suspect that earlier studies on this subject, even those from other regions, overestimated the effects of divestiture on employment due to "small sample sizes, short time series and little ability to control for selection bias." 45

41 Andres et al. (study summarized in capsule no. 3 in the Annex) note that while the workforce reductions in 181 reviewed Latin American infrastructure privatizations totaled 70,000, this number was quite small compared to the total regional labour force. (Luis A. Andres, J. Luis Guasch, Thomas Haven and Vivien Foster, The Impact of Private Sector Participation in Infrastructure, Washington, DC: World Bank-PPIAF, 2008.) McKenzie and Mookherjee reviewed Argentinean, Bolivian and Mexican privatization and concluded that the proportion of the total labour force laid off ranged from 0.013 percent in Bolivia to a high of 2.0 percent in Mexico. They conclude from this that privatization, in Latin America at least, has contributed only slightly to rising unemployment levels. (David McKenzie and Dilip Mookherjee, "Paradox and Perception: Evidence from Four Latin American Countries," Chapter 2 in John Nellis and Nancy Birdsall, eds., Reality Check: The Distributional Impact of Privatization in Developing Countries, Washington, DC: Center for Global Development, 2005, p. 68.)

42 Galal, et al. reached this conclusion in their seminal study, op. cit.

43 Political pressures have resulted in many governments adopting the wasteful practice of offering severance packages to all workers in a firm being privatized, including those slated to be retained by the new private owner.

44 J. David Brown, John S. Earle and Almos Telegdy, "Employment and Wages Effects of Privatization: Evidence from Hungary, Romania, Russia and Ukraine,” The Economic Journal, Vol. 120 (June, 2009), p. 686.

45 Ibid. p. 705. 
The point of all this is that the overall addition to unemployment roles brought about by privatization is smaller than usually thought; that in most instances governments have only reluctantly and under pressure moved against public sector and SOE employees, and when they have, they have taken extraordinary measures to compensate them for the loss of income incurred. ${ }^{46}$

\section{B. PRICES AND ACCESS}

The popular perception is that privatization inevitably raises consumer prices. There is little evidence that this has actually been a common, much less general outcome in privatized firms producing tradables and operating in competitive markets. But, as usual, these are not the contentious cases; complaints centre on infrastructure privatizations, particularly in transport, electricity and water and sewerage. Indeed, it would make some sense if consumer price increases usually did result from most infrastructure privatization, since holding tariffs below cost-recovery levels was a major factor contributing to the poor SOE performance, which, in turn, led to privatization.

Some large price increases have occurred. In the famous case in the Bolivian city of Cochabamba, post-concession water prices for poorer consumers rose by 43 percent, and doubled for a small segment. ${ }^{47}$ Where price hikes of this magnitude have occurred, condemnation and protest have been widespread and swift. ${ }^{48}$

And yet, the empirical evidence does not yield a clear and consistent picture on postprivatization infrastructure pricing. McKenzie and Mookherjee looked at 10 infrastructure privatizations in Latin America and found that prices rose in five and declined in the other five (and even in the cases where prices rose, "...their effects were outweighed by the corresponding increased access" of those in the lower half of the income distribution ${ }^{49}$ ). Andres et al. (Annex summary no. 3) reported a modest upward shift in prices in the 181 Latin

${ }^{46}$ Government generosity has proven very expensive, to the point where Chong and Lopez-de-Silanes, in their discussion of the labour issue, recommended that selling states leave to the new owners the question of which workers should stay and which should go. This would greatly reduce the costs of severance, and also reduce the likelihood of "adverse selection;" i.e., the loss of the able and the retention of the less productive (op. cit., 2002, p. 20). The approach may be economically optimal, but it would greatly escalate the political battles that surround privatization. In addition, in several low-income countries, private buyers have promised to pay the legally established severance to dismissed workers, but have then reportedly failed to do so - and weak or venal officials have not enforced the laws. Laid-off workers have ended up with little or nothing.

47 McKenzie and Mookherjee, op. cit., pp. 49 \& 77.

48 Because water is essential for life, this is the most contentious sector for privatization. For example, Maude Barlow, National Chairperson of the Council of Canadians, Chair of the Board of Food and Water Watch (a research and advocacy NGO), former senior advisor on Water at the United Nations, and author of Blue Covenant: The Global Water Crisis and the Coming Battle for the Right to Water (Toronto: McClelland and Stewart, 2007) speaks for many when she argues that price is not or at least should not be a major issue in water delivery - "no one should be denied access because they can't pay" - and that, "There's no place for the private sector in water delivery. It should be delivered by the public sector on a not-for-profit basis." Private companies "don't see it as their responsibility to provide water for the poor." (Interview with Ms. Barlow by Alexandra Alter, in the Wall Street Journal, November 8, 2008.) These views are widely held, despite substantial developing country experience showing that tariffconstrained SOEs tend to produce an inadequate quantity and a poor quality of water (and electricity as well); that it is the upper income strata that are serviced by the networks; that the poor not connected to the network are paying much higher unit prices for water than the comparatively wealthy; that 40 years of reform/rehabilitation efforts in developing countries to improve and expand public water delivery have produced minimal results; and that there is considerable evidence that private provision of water has in many instances increased access, to better quality water, by the poor.

49 McKenzie and Mookherjee, op. cit., p. 46. 
American infrastructure privatizations they surveyed, but Gassner, Popov and Pushak (Annex summary no. 1) did not find evidence of any such trend in their larger, global study. In telecommunications transactions the overall result has been lower consumer prices, but this may be due as much to the introduction of competitive cellular telephone technology as to ownership change (Annex summary no. 2).

The problem is that post-transaction infrastructure tariffs are a function of a complex set of factors: the nature of the previous tariff regime, the physical state of the network at the time of privatization, the level of unsatisfied demand (and thus the need for funds to rehabilitate and expand the network), the terms of the sales or concession contract concluded, the regulatory frameworks in place, and the authority and competence of the local officials overseeing those frameworks. Existing data simply do not permit unqualified generalizations concerning privatization's effect on consumer prices; outcomes have been decided on a case-by-case basis.

In some cases, consumers have accepted reasonable price increases because they have been accompanied by increased amounts of better quality service. In other cases, consumers have insisted that the better performance precede tariff increases; few utilities have been able to deliver on that promise. ${ }^{50}$ Some analysis has shown that network improvements, traceable to price increases, can result in desirable social outcomes. For example, Galiani, Gertler and Schargrodsky studied a group of Argentine localities that opted for private water delivery. Prices increased. Comparing the localities with private delivery to those that stayed with public provision, the authors argued that "privatization of water services is associated with a reduction of child mortality of 8 percent..." and that "...most of the reduction in mortality occurred in low-income areas (26 percent) where the network expansion was greatest." ${ }^{51}$ Increased access of the poor to clean water was responsible.

Estache (along with several collaborators) has written a number of works in support of the argument that the more competent and effective the regulatory system, the more equitable the distribution of infrastructure privatization's gains. While the efficiency gains from effective regulation flow to all consumers, lower-income groups benefit disproportionately. Estache notes: "The major distributional mandate of regulators is to assess the cost reductions achieved by operators and pass on a fair proportion of those gains to consumers as part of the scheduled tariff-revisions processes." ${ }^{, 52}$

50 Progress can be made: In 2005 the Nairobi City Council turned over water delivery for the metropolitan area to a privately managed group. By vigorous collection and the cut-off of non-payers, the new managers succeeded, for the first time in decades, in covering variable costs, without a tariff increase. This was but a first step; no contributions were made to past debts, depreciation or badly needed capital investments. Moreover, such efforts are hard to sustain. Recent reports are that the City Council has reversed many of the initial reforms.

51 Sebastian Galiani, Paul Gertler and Ernesto Schargrodsky, "Water for Life: The Impact of Privatization of Water Services on Child Mortality," May 30, 2004, version, p. 3; available on the internet from the Social Science Research Network at http://papers.ssrn.com/sol3/papers.cfm?abstract_id=1751702. A slightly different version of the paper was published with the same title in the Journal of Political Economy, Vol. 113, No. 1, 2005, pp. 83-120.

52 Antonio Estache, "Latin America's Infrastructure Experience: Policy Gaps and the Poor," Chapter 8 in Nellis and Birdsall, op. cit., p. 291. 
But in too many countries, industrial states among them, regulators lack experience and authority. This helps explain why new private owners have often captured a disproportionate share of the efficiency gains in the first period after an infrastructure transaction; regulatory agencies are staffing up and regulators are learning their jobs. There is considerable evidence that, as they become more competent, gains become more equitably distributed. However, Estache (and others) notes that the learning process takes longer in institutionally weak developing countries. ${ }^{53}$

The overall thrust of assessments is that there is probably some association of price increases with the privatization of infrastructure operations, but there is a more clear-cut association of increased access with privatization. And, because those in the lower income quintiles or deciles tended to be the least served, network expansion has disproportionately benefited the poor. ${ }^{54} \mathrm{To}$ repeat, consumers, even poor ones, have been willing to pay reasonably increased prices for improved services. Moreover, a group in the World Bank has led a concerted effort to devise and implement subsidy, pricing and administrative procedures to ensure that the poor are protected in infrastructure privatization and reform (through, for example, low block tariffs for the first few units of consumption; subsidizing connection costs, but not prices, in water systems; and a variety of other techniques designed to shelter the least-favoured from the full brunt of needed price increases). ${ }^{55}$ The evidence shows that infrastructure privatization's record on prices and access is not all that bad.

\section{REWARDS THE WRONG AND PUNISHES THE RIGHT?}

Privatization may win many of the economic and even some of the distributional battles - and thus the hearts and minds of Ministers of Finance and many economists - but it is still losing the political war. The fact is that privatization has never been popular among citizenries or electorates in general ${ }^{56}$ and workers, particularly in the public sector, and their union representatives detest it.

The political economy problem of privatization is that, looking beyond the substantial gains to the new owners, the societal benefits of privatization tend to be cumulatively significant but individually small; and in most cases, the small winners - consumers, taxpayers - gain in the medium to longer term. This mass of small winners is generally unorganized and politically inert; few demonstrations have ever been held to applaud more reliable telephone service, a reduction of three percent in electricity tariffs or a modest positive shift in national accounts. In

53 Ibid.

54 Note that these conclusions are best established in the well-studied case of Latin America; one could argue that price and access outcomes are worse in the differing socio-political and institutional circumstances of, say, sub-Saharan Africa. See the studies in Nellis and Birdsall, op. cit., chapters $2-8$.

55 See Antonio Estache, Vivien Foster and Quentin Woodon, Accounting for Poverty in Infrastructure Reform, Washington, DC, Studies in Development Series, World Bank Institute, 2002

56 A detailed illustration from one well-studied region: the polling firm Latinobarometro periodically surveys reactions to political and economic concerns of 19,000 people in 18 Latin American countries, with a total population of more than 400 million. The percentage of respondents who disagree or strongly disagree (four-point scale) with the statement, "privatization of state enterprise has been beneficial for the country" rose from 54 percent in the first survey in 1998 to 78 percent in 2003. In the four surveys undertaken since that date, the percentage of negative opinions has fallen but stayed close to 65 percent. A related statement - "are you satisfied with the privatized services" - has been tested in seven surveys from 2003 to 2010; the percentage of respondents agreeing or strongly agreeing has averaged only 28 percent. See Corporacion Latinobarometro, 2010 Report. Santiago, Chile, 2010, pp. $104 \& 105$. 
contrast, the losers lose large; they feel the pain in the immediate present (i.e., job and salary loss); they tend to be urban, organized and vocal in their opposition to what they frequently term "the privatization beast;" and their plight generally evokes sympathy and support from the media, the intelligentsia and, in non-OECD countries, the development community, including many non-governmental organizations. All this gains the attention of politicians.

Moreover, to broaden their support opponents have drawn attention to proven or alleged cases of corruption in privatization transactions; for example, suspected collusion among bidders (e.g., sale of the electricity utility in Sao Paulo, Brazil), non-transparent post-contract revisions of the sales agreement in favour of the winning bidder (e.g., Tanzania Telecom), the sale of very valuable assets for absurdly low prices to politically connected buyers (e.g., Norilsk Nickel in Russia), and the outright bribery of officials to facilitate or prevent a variety of actions to favour one particular bidder/new owner (numerous cases). ${ }^{57}$

Corruption has certainly occurred in privatization. In countries lacking institutional capacity and well-functioning legal/judicial systems it has been common, very costly to the public purse and highly corrosive of public confidence and faith in the privatization process in particular and market mechanisms in general. Some opponents of privatization insist that the policy inherently and inevitably promotes corruption. Political rivals of privatizing regimes find corruption the easiest of targets and the strongest of rallying points. ${ }^{58}$

What does social science have to say on this subject? Analysts have theorized that, on the one hand, privatization should reduce corruption, as it deprives bureaucrats of opportunities to extract rents, ${ }^{59}$ and, on the other, that it might well increase corruption, since some forms of privatization enhance market concentration and thus amplify rent-seeking prospects. ${ }^{60}$ Corruption is, of course, intrinsically difficult to observe and measure empirically, but it has been attempted. Perhaps not surprisingly, the few studies available reach different conclusions.

57 The three mentioned cases are summarized in John Nellis, "Where public and private merge: privatization and corruption," in Transparency International, Global Corruption Report, 2009, New York, Cambridge University Press, pp. 75-80.

58 See, for one example of many that could be offered, an article on the website of the Civil Service of Pakistan (http://www.cssforum.com.pk/general/news-articles/23630-pakistan-corruption-privatization.html) alleging that privatization in that country has put 600,000 people out of work, that from 1999 to 2007 corruption in privatization transactions cost Pakistan close to \$24 billion US; that massive price hikes have followed all privatizations; and in short, that all the economic ills of Pakistan can be traced to privatization. The proposed solution is renationalization. The negative effects of privatization are mainly asserted, not demonstrated. Where the author gives examples, there is considerable room for doubt. For example, the sale of some banks for less than their book value is seen as proof positive of corruption (and the difference between book and sale value added to the corruption total). This is just as likely to be an indictment of the public ownership, which mismanaged public investments in these banks to the point where their market value at time of sale was a fraction of the amount government had poured in over the years. The dedication of privatization proceeds to debt reduction, and not social expenditures, is seen as more proof of corruption, despite near universal agreement among economists that debt reduction is the optimal use of these onetime gains.

59 The argument is made in Daniel Kauffmann and Paul Siegelbaum, "Privatization and Corruption in the Transition Economies,” Journal of International Affairs, Vol. 50, No. 2 (1997), pp. 419-458.

60 As argued, for example, by Kletil Bjorvatn and Tina Soreide, "Corruption and Privatization," European Journal of Political Economy, Vol. 21 (2005), pp. 903-914. 
Arikan regressed measures of corruption (based on an index found in the International Country Risk Guide) in 73 developing and transition countries on various measures of privatization: "Most results point in the same direction: higher privatization levels seem to increase corruption." ${ }^{61}$ Arikan traced the association to an incomplete severance of the ties between firms and officials (which, as shown above, has been a common outcome when firms are partially privatized, and particularly common in transition states even for firms supposedly wholly divested).

In contrast, in a study of 27 transition (formerly socialist) economies, using data from 1995 through 2008, Koyuncu, Ozturkler and Yilmaz regressed three different corruption indices against six privatization indicators and concluded that there was "strong evidence that privatizations decrease corruption" in these countries. ${ }^{62}$

A middling conclusion was reached by Boubakri, Cosset and Smaoui, who econometrically measured the relationship between privatization and "formal institutions of governance" in a sample of 20 developed and 34 developing countries (none in transition economies), employing a dynamic panel method that examined the association over a 17-year period. They found that "...privatization leads to more corruption in developing countries" while in developed countries it "... leads to an improvement in the quality of law enforcement" and helps "reduce the risk of official corruption." ${ }^{63}$ The authors note that privatizing through the issuing of shares is the optimal - i.e., least conducive to corruption - divestiture method, in both developed and developing economies.

On balance, the evidence and analysis indicates, though far less strongly than many would expect, that privatization probably does increase corruption, at least in lower income, institutionally weak states (but note again the strong counter-conclusion of Koyuncu, Ozturkler and Yilmaz). One can argue about the extent and intensity of corruption; about whether the benefits of efficiency gains and service improvements resulting from privatization are exceeded by the costs of corruption; about whether the rather visible corruption produced by privatization was matched if not exceeded by the extensive if less apparent forms of corruption associated with SOEs - but what one must admit is that the issue is a political bombshell.

Proof of corruption in any formal sense is usually very hard to come by, but it is not needed. When plausible and reasoned allegations of corruption are made of a privatization transaction, especially when combined with evidence of labour layoffs and/or with new ownership by a foreign firm, or by friends and families of the political elite, then, unless the service provided shows rapid and dramatic improvement, the deal, and the process, becomes a political orphan.

${ }^{61}$ G. Guslun Arikan, "How Privatization Affects the Level of Perceived Corruption," Public Finance Review, Vol. 36, No. 6 (November, 2008), p. 724.

62 Cuneyt Koyuncu, Harun Ozturkler and Rasim Yilmaz, "Privatization and Corruption in Transition Economies: Panel Study," Journal of Economic Policy Reform, Vol. 13, Issue 3 (June, 2010), p. 281.

63 Narjess Boubakri, Jean-Claude Cosset and Houcem Smaoui, "Does Privatization Foster Changes in the Quality of Legal Institutions?," Les Cahiers du CREF, Montreal, Graduate School of Commerce (HEC), CREF 07-04, February, 2007, p. 21. 


\section{CONCLUSION}

So, pre-2000, privatization boomed. Post-2000, the pace and number of transactions declined, as did sales proceeds. Proceeds rebounded strongly after 2004 (with a substantial dip in 2008) as the formerly socialist, transition economies shifted from voucher to cash sales, as the larger and more valuable infrastructure, energy, mining and financial firms came to market in many countries, including China and Brazil, and as the EU states re-launched their divestment programs.

China assumed a leading position in privatization in terms of proceeds generated, and the size of enterprises divested. Through 2008, and probably well beyond, it generated numerous large deals and great investor interest. Much of the Chinese activity was partial divestiture through share-issuing, leaving the state with considerable influence. This has led some to ask just what is the nature of the in-between state of so many Chinese firms. No definitive answer has yet emerged.

A good deal of Latin America's privatization had taken place pre-2000. Nonetheless, according to the World Bank, post-2000 the region generated more proceeds from privatization than subSaharan Africa, South Asia or the Middle East-North Africa region. Governments in the latter three areas have, until recently, evidenced limited enthusiasm for privatization, and many transactions they have conducted have been partial sales, with full divestiture limited to smaller, lower-value firms. ${ }^{64}$

Post-2000, privatization through share-issuing became a more important sale method. Shareissuing and negotiated sales, through tenders and a variety of other case-by-case mechanisms, replaced voucher and management buy-out schemes as the most utilized privatization procedures.

Analyses looking at the longer-run impact of the pre-2000 sales, and the shorter-term effects of the more recent privatizations, continued generally to conclude that the process produced financial and operational improvements. In the main, studies confirm that privatized industries evidence increased efficiency (usually labour efficiency, but often increases in total factor productivity as well), increased output, increased investment and produced higher returns to capital. Selling governments usually gained from privatization through sales proceeds, a decrease of financial assistance to loss-making SOEs and an increase in corporate taxation. Most welfare studies reported overall societal economic gains. A number of these studies concluded that negative distributional effects were far less severe than anticipated. However, many also reported losses for labour, as workforce reductions are common and large, both in the run-up to and after the conclusion of the transactions. ${ }^{65}$

\footnotetext{
64 And in some few cases, attempts to divest larger firms in these economies have resulted in spectacular flops. For example, Privatization Barometer reported the failure of the third effort to sell a controlling stake in NITEL (Nigerian Telecom), in March 2011, as the first winning consortium dissolved in legal wrangling, and the second bidder failed to make the required down payment (op. cit., p. 17). PB also reported failures, in 2010, of very large deals in Poland and Korea.

65 Note again the questioning of this conclusion in the important article by Brown, Earle and Telegdy, op. cit. (footnote 44 , above).
} 
Post-2000, despite the positive technical assessments of impact, general enthusiasm for privatization declined. This was due to:

- Repeated financial crises and market downturns, calling into question the liberal approach championed in the 1990s;

- A decline in governmental and investor appetites for privatization;

- A decline in the willingness of the international financial institutions to push for privatization.

Contributing factors included:

- Lurid tales of corrupt privatization (Russia and elsewhere);

- Arguments and evidence that the models of infrastructure privatization espoused in the 1990s were far from foolproof (British Rail, numerous renegotiations of infrastructure concession contracts, the well-publicized cancellation of a number of the same);

- The loss of jobs, and

- Concerns about price increases and fears of diminished access in infrastructure sales, management contracts, leases and concessions.

Empirical studies by and large have presented evidence and arguments that the admitted shorter-term errors and costs of mis-privatization are less widespread and negative than generally perceived, and are or will be outweighed by longer-term economic benefits. A number of studies acknowledge that the bulk of the early gains from infrastructure privatization tend to accrue to new owners. The claim - for which there is considerable evidence - is that as regulators become experienced and skilled, the benefits will be more evenly distributed. In the interim, special compensatory mechanisms can protect the disadvantaged.

Regardless of its technical merits, this position has gained little traction among observers and electorates in developing economies, and has persuaded only a minority in OECD states. Privatization everywhere remains a very hard political sell. The fundamental implementation problem of privatization, particularly in infrastructure, is that in the cases where it goes well, it is close to invisible and taken for granted; but when it goes wrong, or even appears to go wrong, few leaders want anything to do with it.

The upshot is that many governments desperate to improve efficiency and reduce the burdens imposed by loss-making or underperforming SOEs now approach privatization very gingerly. And in trying to design their programs to avoid perceived political problems, they often constrain the new private owners/managers in ways that hinder the achievement of the hopedfor gains. For example, privatization legislation in many developing countries contains proscriptions against workforce reductions (in perpetuity or for a specified number of years), or foreign ownership, or stipulates that government will retain and actively manage a strong minority of shares, or provides for golden shares in the hands of government that must be voted on a variety of operational issues normally in the control of the majority owner, or a combination of or all of the above. As British Rail and other cases demonstrate, half-hearted or half-implemented reforms tend to produce a worst-of-both-worlds situation. 
Given the difficulties in creating and sustaining political support for the concept, the hindrances to doing infrastructure privatization correctly, and the unfavourable market conditions stemming from the continuing economic crisis, it is reasonable to conclude that privatization's future is somewhat uncertain. Note, however, that others disagree; the most recent Privatization Barometer, for example, reads the situation quite differently:

All in all, the future of privatization seems assured ...Longer term, unless economic growth surges to levels unseen in many years, it seems highly likely that western governments will have no choice but to increase privatization sales in order to close yawning budget deficits, and the rapidly growing emerging market countries will choose to sell stakes in their own SOEs for both strategic and financial reasons. Stay tuned.$^{66}$

\footnotetext{
${ }^{66}$ Privatization Barometer, op.cit., p. 5.
} 


\section{ANNEX}

\section{A SELECT SAMPLE OF POST-2000 STUDIES OF PRIVATIZATION}

\section{Water and Electricity Utilities}

Gassner, Popov and Pushak econometrically compared the performance of 301 privately operated (mainly through concessions) water and electricity utilities, in 71 developing and transition countries, to the performance of 926 state-owned utilities in the same sectors and countries. An effort was made to compare "like-to-like" firms and to minimize selection bias. They reported that "...privately operated utilities convincingly outperform state-owned ones in operational performance and labour productivity. ${ }^{97}$ Privately intervened firms produced greater access to services, higher collection rates and increased efficiency compared to SOEs. One substantial downside: the authors found average workforce reductions of roughly 25 percent in the private versus the state managed firms. In addition, they could find no significant differences in investment levels between the two sets of firms, a surprising result since many other studies have reported investment increases post-privatization. Nor could they find “...evidence of a systematic change in prices as a result of" privatization. Neither group of firms moved meaningfully towards cost-recovering pricing. The authors speculate that if the efficiency gains seen in the private firms are producing neither lower prices nor higher investment levels, then it may be that the private operators are reaping most of the benefits (along with the governments that no longer have to subsidize the loss-makers).

\section{Telecommunications}

$\mathrm{Li}$ and $\mathrm{Xu}$ used country-level panel data to assess the impact of privatization and competition in the telecommunications sector in 177 countries, focusing on changes in employment, investment, output, service pricing, network expansion in both fixed and mobile lines, labour productivity and total factor productivity. They found “...robust evidence that both privatization and competition contributed substantially to improve performance along multiple dimensions.. ${ }^{\prime 6}$ Privatization and competition interact to hold down service pricing; the authors view the two policies as complementary and conceptually difficult to separate. Countries that adopted the complete package of divesting a majority stake to a controlling private investor, and opening the sector to competition, "...experienced significantly more performance gain than countries that implemented less aggressive policies." Li and Xu found no significant gains in countries adopting partial privatization and retaining uncompetitive sectors by limiting entry.

67 Katharina Gassner, Alexander Popov and Nataliya Pushak, "Does the private sector deliver on its promises? Evidence from a global study in water and electricity," World Bank, Private Provision of Infrastructure Advisory Fund, Gridline Note No. 36, May, 2008, p. 1. This is a four-page summary of the authors' much longer study. The generally positive findings of this large study are in contrast to the conclusions of an earlier and smaller study on private participation in water in Africa which could not find appreciable differences in performance between publicly and privately managed firms. See Colin Kirkpatrick, David Parker and Yin-Fang Zhang, "State Versus Private Provision of Water Services in Africa: An Empirical Analysis," World Bank Economic Review, Vol. 20, No. 1, pp. 143-163.

${ }^{68}$ Wei Li and Lixin Colin Xu, "The Impact of Privatization and Competition in the Telecommunications Sector Around the World," Journal of Law and Economics, Vol. 47, No. 2, August, 2004, p. 32. 
While data limitations prevented a complete welfare analysis, the authors speculated that under full privatization, consumers, sellers and taxpayers all gained, while workers, many of whom were laid off, lost (but those retained gained wage increases).

\section{Infrastructure Privatization in Latin America}

Andres et al. analyzed the effects of private sector participation over a 10-year period in 181 Latin American firms in electricity, water and sewerage and telecommunications. The authors applied a variety of econometric and cost-benefit tests to determine the effects of private involvement. Their main conclusion was that "...significant improvements in sector performance were associated with private sector participation." ${ }^{\prime 99}$ They found increases in efficiency and service quality. Distributional losses declined. There were substantial reductions in the labour force; between 15 and 25 percent in the period of transition to privatization, and an additional 15-25 percent reductions in the first few years following ownership change. Coverage (access) increased, as did prices, though the authors found it hard to generalize on the latter.

\section{Banks}

Megginson surveyed the empirical literature on the results of bank privatization in OECD, transition, and non-transition developing countries, looking at 250 instances in 59 countries. He concluded: "Privatization generally improves performance, but by far less than is typically observed in non-financial studies." ${ }^{70}$ The results vary greatly by region. Bank privatization generally yields strongly positive results in OECD countries. In transition economies, those banks privatized to foreign investors have performed well; those placed in the hands of local investors, much less well. In non-transition developing economies, the record is even "more mixed," with only those banks divested to core investors showing highly positive results. In this successful group, the foreign owners produced the best results.

Boubakri et al. elaborated on this last point. They looked specifically at 81 bank privatizations in 22 developing countries, and observed that banks selected for privatization tended to be poor performers, showing lower rates of economic efficiency and solvency than those retained in state hands. Immediately following privatization, profitability increased, but there were declines in efficiency and capitalization, and an increase in risk exposures. However, their data show that over time, "privatization yields significant improvements in economic efficiency and capital risk exposures." 71

69 Luis A. Andres, J. Luis Guasch, Thomas Haven and Vivien Foster, The Impact of Private Sector Participation in Infrastructure, Washington, DC: World Bank-PPIAF, 2008, p. 224. See also Alberto Chong and Florencio Lopez-deSilanes, eds., Privatization in Latin America: Myths and Reality, Washington, DC: The World Bank, 2005. This compilation reviews the effects of privatization in Argentina, Bolivia, Brazil, Chile, Colombia, Mexico and Peru. The editors conclude that privatization in this region generally leads “....to higher profitability, but also to large output and productivity growth, fiscal benefits and even quality improvements and better access for the poor" (p. 6).

70 William L. Megginson, "The economics of bank privatization," Journal of Banking and Finance, Vol. 29 (2005), p. 1931.

71 Narjess Boubakri, Jean-Claude Cosset, Klaus Fischer and Omrane Guedhami, "Privatization and Bank Performance in Developing Counties," Journal of Banking and Finance, Vol. 29, 2005, p. 2015. 


\section{Privatization in Transition Economies, including China}

Estrin et al. reviewed the extensive literature on the impact of privatization in post-socialist societies in transition economies in East, Central and South Europe, Central Asia and China. They examined the effects of privatization on efficiency, profitability and revenues.

The effect of privatization is mostly positive in Central Europe, but quantitatively smaller than that to foreign owners and greater in the later than earlier transition period. In the Commonwealth of Independent States, privatization to foreign owners yields a positive or insignificant effect while privatization to domestic owners generates a negative or insignificant effect. The available papers on China find diverse results, with the effect of nonstate ownership on total factor productivity being mostly positive but sometimes insignificant or negative..$^{22}$

Others reached much stronger conclusions regarding the Chinese experience. En-Bai, Lu and Tao assessed the impact of partial to full privatization on 2,866 Chinese firms, and found that ownership change had a significant positive impact on financial and operational performance; the greater the degree of private ownership, the greater the positive effects. ${ }^{73}$

Brown, Earle and Telegdy conducted a long-term study of the productivity effects of privatization in Hungary, Romania, Russia and Ukraine, using "comprehensive data on manufacturing firms in the four countries," and found

a substantial positive effect of privatization on productivity in Romania, with a range of estimates in the unweighted regressions from 15 to 50 percent ...The estimated effects are also positive for Hungary, with a range from 8 to 28 percent...In both of these countries, the estimated effects are always highly significantly different from zero. For Ukraine, the estimated effects are positive but always much lower - from 2 to 16 percent - and they are sometimes statistically insignificant. Finally, we estimate an effect from -5 to 14 percent in Russia. ${ }^{74}$

The authors find that privatization to foreign investors consistently results in superior productivity. The positive impact of privatization occurs immediately in Hungary and Romania, after a year in Ukraine, and not until the fifth post-privatization year in Russia, ${ }^{75}$ leading the authors to conclude that privatization matters, but that the method of divestiture and the country conditions heavily influence the outcomes.

72 Saul Estrin, Jan Hanousek, Evzen Kocenda and Jan Svejnar, "The Effects of Privatization and Ownership in Transition Economies," Journal of Economic Literature, Vol. 47, No. 3 (September, 2009), p. 699. (The Commonwealth of Independent States is an association of the countries that were, pre-1991, part of the USSR, minus Estonia, Latvia, Lithuania and Georgia.)

73 Chong En-Bai, Jiang Yong Lu and Zhigang Tao, "How Does Privatization Work in China?” Journal of Comparative Economics, Vol. 37, No. 3 (September, 2009), from the abstract.

74 J. David Brown, John S. Earle and Almos Telegdy, "The Productivity Effects of Privatization: Longitudinal Estimates from Hungary, Romania, Russia and Ukraine," Journal of Political Economy, Vol. 114, No. 1, 2006, p. 89.

75 Ibid., p. 90. 


\section{Electricity sector reform in developing countries}

Zhang, Parker and Kirkpatrick carried out an econometric analysis of the relative effects of privatization, altered regulation and exposure to competition in the electricity generation sectors in 36 developing and transition countries, looking specifically at the interactions among the three policies/factors. The principal finding was that "competition in electricity generation is more important than privatization or the establishment of independent regulation in bringing about performance improvements. ${ }^{, 76}$ The authors found that privatization did not lead to significant improvements in labour productivity, capital utilization, generating capacity or output, except in cases where ownership change was combined with independent regulation. Regulation by itself was ineffective in the absence of privatization. The analysis concluded that “...increased exposure to competition was of overwhelming importance" in explaining increases in all four performance measures. ${ }^{77}$

\section{The Partial Privatization of British Rail}

In his penultimate book, Ill Fares the Land, the late Tony Judt excoriated the last quarter of the 20th century's "worship of the private sector and, in particular, the cult of privatization." Generalizing from the experience of Great Britain, Judt argued that privatization did not produce the anticipated efficiency and operational gains in the transferred services and infrastructure. Privatization's more typical outcome, he argued, was to hand over assets at bargain prices to private owners who pocketed the profits while "...charging losses to the state. The outcome has been the worst sort of 'mixed economy': individual enterprise indefinitely underwritten by public funds." In illustration, he cited the cases of the London Underground and British Rail, which were partially privatized in the 1990s, and subsequently suffered operational or financial crises that required them, according to Judt, "to turn back to government to pick up the bill." The privileged private operators of "vital national services ...could take risks, misspend or misappropriate resources at will, and always know that the government would pick up the tab."78

Judt's critique is more assertive than empirical. But his negative view is held by about threequarters of the British public, which thinks that rail privatization produced increased costs, lower quality and unsafe services, huge, unjustified salaries and bonuses to the new operators, and increased debt to the state. Are these views accurate?

Glaister's detailed study looked at British Rail performance and policy changes from the introduction of private involvement through 2004 (the year in which the last major change in rail policy took place). He states that the "fundamental principle" of the initial reform had not been ownership change, but rather the introduction or enhancement of competition in all aspects of the rail business. To that end, in the mid-1990s the Conservative government placed all rail infrastructure - tracks, tunnels, bridges, signaling and stations - in the hands of a new

\footnotetext{
76 Yin-Fang Zhang, David Parker and Colin Kirkpatrick, "Electricity Sector Reform in Developing Countries: An Econometric Assessment of the Effects of Privatization, Competition and Regulation," Journal of Regulatory Economics, Vol. 33, No. 2, April, 2008, p. 20 of an on-line version of the article.

77 Ibid

78 All citations found in Judt, 2010, Chapter 3, sub-section "The Cult of the Private." (Page numbers cannot be given, as this is an electronic edition read on a Kindle. The arguments given here are found at the 46 percent mark of the text.)
} 
government corporation called Railtrack. Private operators in passenger, freight and urban rail services were to compete for franchises to use portions of this infrastructure. The assumption was that competition among private providers would result in revenues to the franchiser (the state), improved quality and quantity of service, and lower costs. The policy was at first wellimplemented and, according to Glaister and others, "it started to produce some remarkably good results." 79

Several financial/political factors then arose that led the government to modify or abandon its emphasis on competition enhancement. First, it was seen that to make the competition policy function as designed would push a number of unanticipated costs on to the public purse.

Treasury and the government demurred. Second, no proper competition was held for some of the most important franchises. Glaister suggests this may have been due to government thinking it could maximize the revenues from the franchise fees by limiting the competition to the largest potential bidders. ${ }^{80}$ Third, neither the Conservative nor the successor Labour government allowed the competitive process to work to the point where it would result in exit for poorly performing franchise operators. When these got into financial trouble, successive governments allowed them to raise their prices to cover their costs. This, says Glaister, "destroyed the normal competitive market for corporate control." Fourth, very limited competition was allowed in the rail labour markets. Open competition in this area had, according to Glaister, been a principal factor accounting for the efficiency gains made in all other privatized British infrastructure industries. Fifth, in 2002 Railtrack itself ran into great financial difficulties (through faulty government oversight, argues Glaister). It too was rescued; it was "sold" to a new firm - presently called National Rail Infrastructure Limited - which is a "non-dividend paying company limited by guarantee" that does not have shareholders, but rather 100 non-remunerated "members," 80 percent of whom are volunteers from the general rail-using public. $^{81}$

In sum, the whole rail system has been "set precariously on an indistinct boundary between the public and private sectors, with foggy corporate objectives and ill-defined duties toward the public sector." The experience ended by producing "...the worst of all worlds: to incur the costs of privatization in order to harness the forces of competition, but then to intervene to prevent that competition from delivering the benefits." ${ }^{\prime 2}$

Glaister thus confirms Judt's broadest brushstrokes. But the thrust of Glaister's study is not that restructuring/privatization/competition enhancement was wrong in principle, but rather that it was not allowed to work. He states: “... it is pointless for governments to introduce... (competition) unless they can deliver on the commitment to allow it to function." ${ }^{83}$

79 Stephen Glaister, "British Rail Privatization: Competition Destroyed by Politics," CRI Occasional Paper No.23, Center for the Study of Regulated Industries, University of Bath, 2004, p. 54.

80 Ibid., p. 54. See also M. G. Pollitt and A. S. J. Smith, "The Restructuring and Privatization of British Rail: Was it Really that Bad?," Fiscal Studies, Vol. 23, No. 4 (2002), which reported impressive positive results in privatized rail up to 2000 .

81 A British company limited by guarantee corresponds roughly to the North American not-for-profit firm. By law, National Rail is supposed to operate in the same manner as a publicly listed company. It is managed by a Board of Directors of 14, drawn from relevant professions, and is subject to external audit. The Board answers to the members and to the Office of Rail Regulation.

82 Glaister, op. cit., p. 55. Note that limiting the number of bidders is, according to auction theory, likely to depress, not raise, the price.

83 Ibid. 


\section{BIBLIOGRAPHY}

Andres, Luis, J. Luis Guasch, Thomas Haven and Vivien Foster, 2008. The Impact of Private Sector Participation in Infrastructure, Washington, DC: World Bank-PPIAF.

Arikan, G. Guslan, 2008. "How Privatization Affects the Level of Perceived Corruption," Public Finance Review, Vol. 36, No. 6.

Aslund, Anders, 2007. How Capitalism was Built: The Transformation of Central and Eastern Europe, Russia and Central Asia. Cambridge: MIT Press.

Barlow, Maude, 2007. Blue Covenant: The Global Water Crisis and the Coming Battle for the Right to Water, Toronto: McClelland and Stewart.

Bevan, Alan, Saul Estrin and Mark Schaffer, 1999. "Determinants of Enterprise Performance During Transition," Birmingham, U.K.: Centre for Environmental Research and Training, University of Birmingham, Working Paper No. 3.

Bjorvatn, Kletil and Tina Soreide, 2005. "Corruption and Privatization,” European Journal of Political Economy, Vol. 21, pp. 903-914.

Black, Bernard, R. Kraakman and A. Tarassova, 2000. "Russian Privatization and Corporate Governance: What Went Wrong?," Stanford Law Review, Vol. 52, pp. 1731-1808.

Boardman, Anthony E., Claude Laurin, Mark A. Moore and Aidan R. Vining, 2009. "A Cost-Benefit Analysis of the Privatization of Canadian National Railway," Canadian Public Policy, Vol. 35, No. 1, March, pp. 59-83.

Boubakri, Narjess and Jean-Claude Cosset, 1998. "The Financial and Operating Performance of Newly Privatized Firms: Evidence from Developing Countries," Journal of Finance, Vol. LIII, No. 3 (June, 1998), pp. 1081-1110.

Boubakri, Narjess, Jean-Claude Cosset, Klaus Fischer and Omrane Guedhami, 2005. "Privatization and Bank Performance in Developing Counties," Journal of Banking and Finance, Vol. 29, pp. 2015-2041.

Boubakri, Jean-Claude Cosset and Houcem Smaoui, 2007. "Does Privatization Foster Changes in the Quality of Legal Institutions?" Les Cahiers du CREF, Montreal, Graduate School of Commerce (HEC), CREF 07-04, February.

Brown, J. David, John S. Earle and Almos Telegdy, 2006. "The Productivity Effects of Privatization: Longitudinal Estimates from Hungary, Romania, Russia and Ukraine," Journal of Political Economy, Vol. 114, No. 1, pp. 61-99.

Brown, J. David, John S. Earle and Almos Telegdy, 2009. "Employment and Wages Effects of Privatization: Evidence from Hungary, Romania, Russia and Ukraine," The Economic Journal, Vol. 120 (June), pp. 683-708.

Chong, Alberto and Florencio Lopez-de-Silanes, 2002. "Privatization and Labour Force Restructuring around the World," World Bank, Policy Research Working Paper No. 2884, September.

Chong, Alberto and Florencio Lopez-de-Silanes, eds., 2005. Privatization in Latin America: Myths and Reality, Washington, DC: The World Bank.

Corporacion Latinobarometro, 2010. 2010 Report, Santiago, Chile.

Davis, Jeffrey, Rolando Ossowski, Thomas Richardson and Steven Barnett, 2000. "Fiscal and Macroeconomic Impact of Privatization,” International Monetary Fund, Occasional Paper No. 194.

Domah, P. and M. G. Pollitt, 2000. "The Restructuring and Privatization of Electricity Distribution and Supply Businesses in England and Wales: A Social Cost-Benefit Analysis," Working Paper No. 7 , University of Cambridge Department of Applied Economics.

En-Bai, Chong, Jiang Yong Lu and Zhigang Tao, 2009. "How Does Privatization Work in China?" Journal of Comparative Economics, Vol. 37, No. 3 (September). 
Estache, Antonio, Vivien Foster and Quentin Woodon, 2002. Accounting for Poverty in Infrastructure Reform, Washington, DC, Studies in Development Series, World Bank Institute.

Estrin, Saul, Jan Hanousek, Evzen Kocenda and Jan Svejnar, 2009. "The Effects of Privatization and Ownership in Transition Economies," Journal of Economic Literature, Vol. 47, No. 3 (September).

European Bank of Reconstruction and Development, 2010. Transition Report 2010: Recovery and Reform. London.

Florio, Massimo, 2004. The Great Divestiture: Evaluating the Welfare Impact of the British Privatizations. Cambridge: MIT Press.

Freedland, Chrystia, 2000. Sale of the Century: Russia's Wild Ride from Communism to Capitalism. London: Crown Business Books.

Galal, Ahmed, Leroy Jones, Pankaj Tandon and Ingo Vogelsang, 1995. Welfare Consequences of Selling Public Enterprises. Washington, DC: World Bank.

Galiani, Sebastian, Paul Gertler and Ernesto Schargrodsky, 2004 "Water for Life: The Impact of Privatization of Water Services on Child Mortality," May 30, 2004, version, p. 3; available on the internet from the Social Science Research Network at

http://papers.ssrn.com/sol3/papers.cfm?abstract_id=1751702. A slightly different version of the paper was published with the same title in the Journal of Political Economy, Vol. 113, No. 1, 2005, pp. 83-120.

Gassner, Katharina, Alexander Popov and Nataliya Pushak, 2008. "Does the private sector deliver on its promises? Evidence from a global study in water and electricity," World Bank, Private Provision of Infrastructure Advisory Fund, Gridline Note No. 36, May.

Glaister, Stephen, 2004. "British Rail Privatization: Competition Destroyed by Politics," CRI Occasional Paper No.23, Center for the Study of Regulated Industries, University of Bath.

Goldstein, Andrea and Guisieppe Nicoletti, 2003. "Privatization in Italy 1993-2002: Goals, Institutions, Outcomes and Outstanding Issues," Paris, OECD Development Center Working Paper.

Guasch, J. Luis, 2004. Granting and Renegotiating Infrastructure Concessions. Washington: World Bank.

Gupta, Nandini, 2005. "Partial Privatization and Firm Performance," Journal of Finance, Vol. 60, Issue 2 (April, 2005), pp. 987-1015.

Gupta, Nandini, John C. Ham and Jan Svejnar, 2001. "Priorities and Sequencing in Privatization Theory and Evidence from the Czech Republic," William Davidson Institute Working Paper No. 323, University of Michigan, September.

Harris, Clive, 2003. "Private Participation in Infrastructure in Developing Countries," World Bank Working Paper No. 5.

Havrylyshyn, Oleh and D. McGettigan, 2000. "Privatization in Transition Economies," Post-Soviet Affairs, Vol. 16, 2000, pp. 257-286.

Havrylyshyn, Oleh and Saleh M. Nsouli, editors, 2001. A Decade of Transition: Achievements and Challenges. Washington, DC: International Monetary Fund.

Jones, Leroy, Yahya Jammal, Nilgün Gökgür and Sunita Kikeri, 2008. "Doing Privatization Right: What it Takes to Maximize Gains in Low-income Countries," World Bank, Viewpoint No. 319.

Judt, Tony, 2010. Ill Fares the Land, N.Y., The Penguin Press.

Kauffmann, Daniel and Paul Siegelbaum, 1997. "Privatization and Corruption in the Transition Economies," Journal of International Affairs, Vol. 50, No. 2, pp. 419-458.

Kikeri, Sunita and Aishetu Kolo, 2006. "Privatization Trends," World Bank, Public Policy for the Private Sector Note No. 303.

Kikeri, Sunita and Aishetu Kolo, 2006. "State Enterprises: What Remains?" World Bank, Public Policy for the Private Sector, Note Number 304. 
Kikeri, Sunita and Verena Phipps, 2007. "Privatization Trends: A Record Year for Initial Public Offerings in 2007," World Bank, Viewpoint: Public Policy for the Private Sector.

Kikeri, Sunita and Matthew Perault, 2010. "Privatization Trends: A Sharp Decline but no Widespread Reversals," World Bank, Viewpoint: Public Policy for the Private Sector, Note Number 332, May.

Kirkpartick, Colin, David Parker and Yin-Fang Zhang, 2006. "State Versus Private Provision of Water Services in Africa: An Empirical Analysis," World Bank Economic Review, Vol. 20, No. 1, pp. 143-163.

Koyuncu, Cuneyt, Harun Ozturkler and Rasim Yilmaz, 2010. "Privatization and Corruption in Transition Economies: A Panel Study,” Journal of Economic Policy Reform, Vol. 13, Issue 3 (June), pp. 277-284.

La Porta, Raphael and Florencio Lopez-de-Silanes, "The Benefits of Privatization: Evidence from Mexico," Quarterly Journal of Economics, Vol. 114, No. 4 (November, 1999), pp. 1193-1242.

Lee, Junyeop, 2009. "State-Owned Enterprises in China: Reviewing the Evidence," OECD Occasional Paper, Organization for Economic Cooperation and Development Working Group on Privatization and Corporate Governance of State-Owned Assets, Paris.

Lee, Sang-Ho, 2006. "Welfare Improving Privatization Policy in the Telecommunications Industry," Contemporary Economic Policy, Vol. 24, Issue 2, April, pp. 237-248.

$\mathrm{Li}$, Wei and Lixin Colin $\mathrm{Xu}, 2004$. "The Impact of Privatization and Competition in the Telecommunications Sector Around the World," Journal of Law and Economics, Vol. 47, No. 2, August, pp. 37.

Lieberman, Ira and Rogi Veimetra, 1996. "The Rush for State Shares in the "Klondyke" of Wild-East Capitalism: Loans-for-Shares Transactions in Russia," The George Washington Journal of International Law and Economics, Vol. 29 (No. 3).

Lieberman, Ira and Daniel Kopf, eds., 2008. Privatization in Transition Economies: The Ongoing Story, New York, Elsevier.

Loc, Truong Dong, Ger Lanjouw and Robert Lensinck, 2006. "The impact of privatization on firm performance in a transition economy: The case of Vietnam," Economics of Transition, Vol. 14, No. 2, 2006, 349-389.

Megginson, William and Jeffrey Netter, "From state to market: A survey of empirical studies on privatization," Working Paper, New York Stock Exchange and SBF Bourse de Paris. Revised version published by the authors in 2001. "From State to Market: A Survey of Empirical Studies on Privatization," Journal of Economic Literature, Vol. XXXIX, (June, 2001), pp. 321-389.

Megginson, William L., 2005. "The economics of bank privatization," Journal of Banking and Finance, Vol. 29, pp. 1931-1980.

Mota, Rafaella Lisboa, 2003. "The Restructuring and Privatization of the Electricity Distribution and Supply Businesses in Brazil: A Social Cost-Benefit Analysis," Working Paper 16, University of Cambridge, Department of Applied Economics.

Nellis, John and Nancy Birdsall, eds., Reality Check: The Distributional Impact of Privatization in Developing Countries, Washington, DC: Center for Global Development.

Nellis, John, 2007. "Privatization: A Summary Assessment," The SAIS Review of International Affairs, Summer-Fall 2007, Vol. XXVII (No. 2), pp. 3-29.

Nellis, John, 2009. "Where public and private merge: privatization and corruption," in Transparency International, Global Corruption Report, 2009, New York, Cambridge University Press, pp. 75-80.

Newbery, David and M. G. Pollitt, 1997. "The Restructuring and Privatization of Britain's CEGB: Was it Worth It?” Journal of Industrial Economics, Vol. 45, No. 3, pp. 269-303.

OECD, 2002. "Recent Privatization Trends in OECD Countries," OECD, Paris.

Pollitt, M. G. and A. S. J. Smith, 2002. "The Restructuring and Privatization of British Rail: Was it Really that Bad?" Fiscal Studies, Vol. 23, No. 4. 
Pollitt, M. G., 2009. "The Welfare Implications of Oil Privatization: A Cost-Benefit Analysis of Norway's Statoil," University of Cambridge, Faculty of Economics Working Paper No. 0912, March.

Privatization Barometer, 2010. The PB Report, 2010, Milan, (www.privatizationbarometer.net).

Roland, Gerard, editor, 2008. Privatization Successes and Failures, N.Y., Columbia University Press.

Shleifer, Andrei and Daniel Treisman, 2000. Without a Map: Political Tactics and Economic Reform in Russia. Cambridge: MIT Press.

Stiglitz, Joseph, 1999. "Quis Custodiet Ipsos Custodes? Corporate Governance Failures in the Transition," Annual European World Bank Conference on Development Economics, Paris: June.

Tandon, Pankaj, 1995. "Welfare Effects of Privatization: Some Evidence from Mexico," Boston University International Law Journal, Vol. 13, No. 2 (1995), pp. 329-49.

Williamson, John, 1990. "What Washington Means by Policy Reform," Chapter 2 in John Williamson, ed., Latin American Adjustment, Washington, DC, Institute of International Economics.

World Bank, 2009. Privatization Database, http://ru.worldbank.org/Privatization/.

Zhang, Yin-Fang, David Parker and Colin Kirkpatrick, 2008. "Electricity Sector Reform in Developing Countries: An Econometric Assessment of the Effects of Privatization, Competition and Regulation," Journal of Regulatory Economics, Vol. 33, No. 2, April. 


\section{ABOUT THIS PUBLICATION}

The School of Public Policy Research Papers provide in-depth, evidence-based assessments and recommendations on a range of public policy issues. Research Papers are put through a stringent peer review process prior to being made available to academics, policy makers, the media and the public at large. Views expressed in The School of Public Policy Research Papers are the opinions of the author(s) and do not necessarily represent the view of The School of Public Policy.

\section{OUR MANDATE}

The University of Calgary is home to scholars in 16 faculties (offering more than 80 academic programs) and 36 Research Institutes and Centres including The School of Public Policy. Under the direction of Jack Mintz, Palmer Chair in Public Policy, and supported by more than 100 academics and researchers, the work of The School of Public Policy and its students contributes to a more meaningful and informed public debate on fiscal, social, energy, environmental and international issues to improve Canada's and Alberta's economic and social performance.

The School of Public Policy achieves its objectives through fostering ongoing partnerships with federal, provincial, state and municipal governments, industry associations, NGOs, and leading academic institutions internationally. Foreign Investment Advisory Committee of the World Bank, International Monetary Fund, Finance Canada, Department of Foreign Affairs and International Trade Canada, and Government of Alberta, are just some of the partners already engaged with the School's activities.

For those in government, The School of Public Policy helps to build capacity and assists in the training of public servants through degree and non-degree programs that are critical for an effective public service in Canada. For those outside of the public sector, its programs enhance the effectiveness of public policy, providing a better understanding of the objectives and limitations faced by governments in the application of legislation.

\section{DISTRIBUTION}

Our publications are available online at www.policyschool.ca.

\section{DISCLAIMER}

The opinions expressed in these publications are the authors' alone and therefore do not necessarily reflect the opinions of the supporters, staff, or boards of The School of Public Policy.

\section{COPYRIGHT}

Copyright (C) 2012 by The School of Public Policy.

All rights reserved. No part of this publication may be reproduced in any manner whatsoever without written permission except in the case of brief passages quoted in critical articles and reviews.

\section{ISSN}

1919-112x SPP Research Papers (Print)

1919-1138 SPP Research Papers (Online)

\section{DATE OF ISSUE}

January 2012

\section{MEDIA INQUIRIES AND INFORMATION}

For media inquiries, please contact Morten Paulsen at 403-453-0062.

Our web site, www.policyschool.ca, contains more information about The School's events, publications, and staff.

\section{DEVELOPMENT}

For information about contributing to The School of Public Policy, please contact Candice Naylen by telephone at 403-210-7099 or by e-mail at cnaylen@ucalgary.ca.

\section{EDITOR}

Timothy Giannuzzi 


\section{RECENT PUBLICATIONS BY THE SCHOOL OF PUBLIC POLICY}

HOUSING SUBSIDIES AND HOMELESSNESS: A SIMPLE IDEA

http:// policyschool.ucalgary.ca/sites/default/files/research/oflaherty-housing-subsidy.pdf Brendan O'Flaherty | January 2012

PUBLIC SECTOR WAGE GROWTH IN ALBERTA

http:// policyschool.ucalgary.ca/sites/default/files/research/boesenkool-public-wage-growth.pdf Ken Boessenkool and Ben Eisen | January 2012

CATCHING THE BRASS RING: OIL MARKET DIVERSIFICATION POTENTIAL FOR CANADA http:// policyschool.ucalgary.ca/ sites/default/files/research/mmoore-oilmarket.pdf M.C. Moore, S. Flaim, D. Hackett, S. Grissom, D. Crisan and A. Honarvar | December 2011

THE CONSTITUTIONALITY OF FEDERAL CLIMATE CHANGE LEGISLATION

http:// policyschool.ucalgary.ca/ ?q=content/constitutionality-federal-climate-change-legislation Alastair Lucas and Jenette Yearsley | December 2011

THE MYTHS AND FACTS OF FOSSIL FUEL SUBSIDIES: A CRITIQUE OF EXISTING STUDIES http:/ / policyschool.ucalgary.ca/files/ publicpolicy/MCKENZIE\%20MINTZ\%20online.pdf Kenneth J. McKenzie and Jack M. Mintz | October 2011

HOMELESSNESS IN ALBERTA: THE DEMAND FOR SPACES IN ALBERTA'S HOMELESS SHELTERS http:/ / policyschool.ucalgary.ca/files/publicpolicy/ homelessness\%20in\%20alberta.pdf Ronald Kneebone, J.C. Herbert Emery and Oksana Grynishak | September 2011

THE NEW SECURITY PERIMETER WITH THE UNITED STATES

http:// policyschool.ucalgary.ca/files/ publicpolicy/flemming\%20sept011.pdf Brian Flemming | September 2011

INCOME SUPPORT FOR PERSONS WITH DISABILITIES http:// policyschool.ucalgary.ca/files/publicpolicy/Kneebone_Disability_Study.pdf Ronald Kneebone and Oksana Grynishak | September 2011

INVESTMENT REVIEW IN CANADA - WE CAN DO BETTER http:/ / policyschool.ucalgary.ca/files/publicpolicy/Herman\%20Invest\%20Canada\%20online.pdf Lawrence L. Herman | September 2011

PLUCKING THE GOLDEN GOOSE: HIGHER ROYALTY RATES ON THE OIL SANDS GENERATE SIGNIFICANT INCREASES IN GOVERNMENT REVENUE http:/ / policyschool.ucalgary.ca/files/publicpolicy/KMckenzie\%20comm\%20sept11.pdf Kenneth J. McKenzie | September 2011

ENVIRONMENTAL BENEFITS OF USING WIND GENERATION TO POWER PLUG-IN HYBRID ELECTRIC VEHICLES http:/ / policyschool.ucalgary.ca/files/ publicpolicy/enviro\%20hybrid\%20wind\%20energy.pdf Mahdi Hajian, Monishaa Manickavasagam, William D. Rosehart and Hamidreza Zareipour | August 2011

A FRESH START ON IMPROVING ECONOMIC COMPETITIVENESS AND PERIMETER SECURITY

http:/ / policyschool.ucalgary.ca/files/ publicpolicy/dburney.pdf

Derek H. Burney | August 2011

PIIGS “Я” US?

http:// policyschool.ucalgary.ca/files/ publicpolicy/US\%20debt\%20crisis.pdf

Stephen R. Richardson | July 2011 